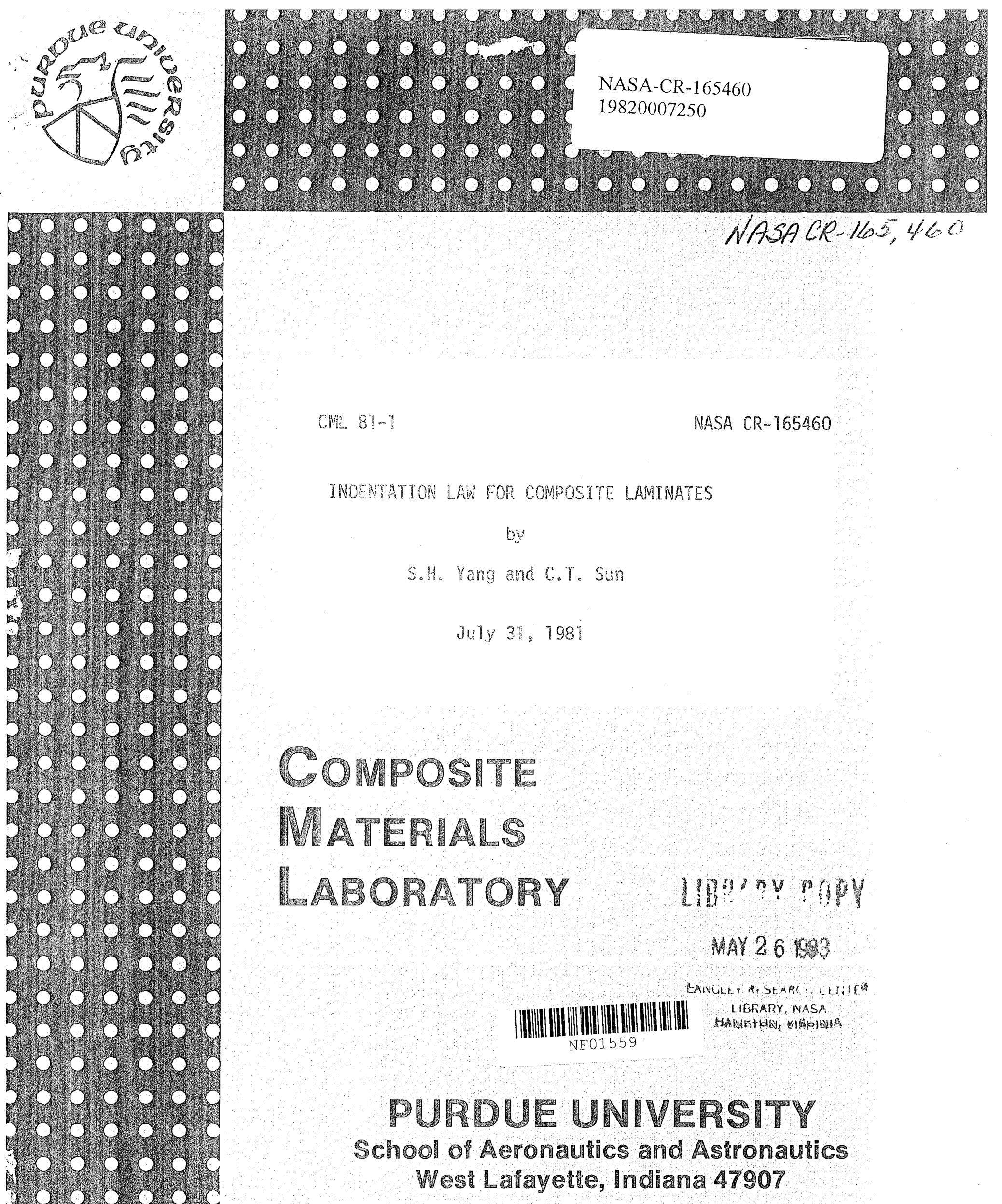


CML $81-1$

NASA CR- 165460

\section{INDENTATION LAW FOR COMPOSITE LAMINATES}

by

S.H. Yang and C.T. Sun

Juty 31,1981

NASA GRANT NSG 3185

19n-1Kप0? 


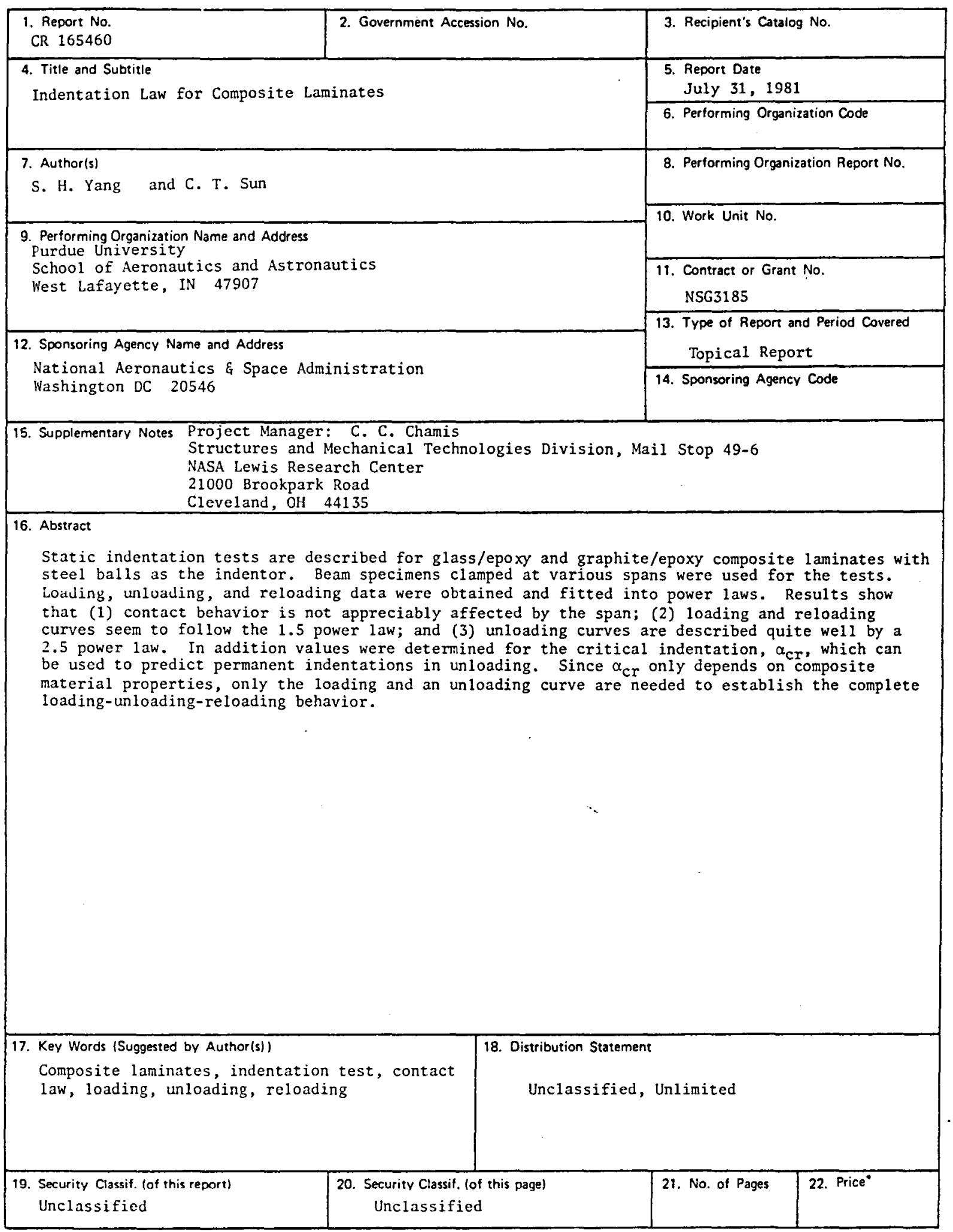

- For sale by the National Technical Information Service. Springfield. Virginia 22161 


\section{TABLE OF CONTENTS}

page

Table of Contents .................. . . i . . . . . .

List of Tables.................... iv List of Figures . . . . . . . . . . . . . . . v Nomenclature ................... vii

1. Introduction. ................... 1

2. Hertzian Law of Contact ............... 2

3. Experimental Procedures ............... 4

4. Experimental Results and Modeling . . . . . . . . . 5

4.1 Loading Curve ................ 5

4.2 Unloading Curve .............. . 7

4.3 Reloading Curve ................ 11

5. Discussion. ............... 12

6. References ................ 14 


\section{LIST OF TABLES}

Table 1 - Loading law $F=k \alpha^{n}$ for glass/epoxy with $6.35 \mathrm{~mm}$ diameter indentor, $F$ in $N$ and $\alpha$ in m ( $F$ in $1 b$ and $\alpha$ in inch).

Table 2 - Loading law $F=k \alpha^{1.5}$ for $[0 / 45 / 0 /-45 / 0]_{2 s}$ graphite/ epoxy; $F$ in $N$ and $\alpha$ in $\mathrm{mm}$ ( $F$ in $\mathrm{Ib}$ and $\alpha$ in inch).

Table 3 - Values of $\alpha_{0}$ and area under the unloading curve by different fits for glass/epoxy.

Table 4 - Values of $\alpha_{0}$ and area under the unloading curve by different fits for graphite/epoxy with $6.35 \mathrm{~mm}$ (0.25 in.) indentor.

Table 5 - Values of $\alpha_{0}$ and area under the unloading curve by different fits for graphite/epoxy with $12.7 \mathrm{~mm}$ (0.5 in.) indentor.

Table 6 - Comparison of loading rigidity $k$ and reloading rigidity $k_{1}$ for graphite/epoxy with $12.7 \mathrm{~mm}$ (0.5 in.) indentor.

Table 7 - Values of $k^{\prime}$ for graphite/epoxy (Equation (19)). 
Fig. 1 - Indentation test set-up.

Fig. 2 - Least-square fit for loading for glass/epoxy with $50.8 \mathrm{~mm}\left(2^{\prime \prime}\right)$ span and $6.35 \mathrm{~mm}\left(0.25^{\prime \prime}\right)$ diameter indentor.

Fig. 3 - Least-square fit for loading with $n=1.5$ for glass/epoxy with $50.8 \mathrm{~mm}\left(2^{\prime \prime}\right)$-span and $6.35 \mathrm{~mm}\left(0.25^{\prime \prime}\right)$ diameter indentor.

Fig. 4 - Least-square fit for loading with $n=1.5$ for graphite/epoxy with $50.8 \mathrm{~mm}\left(2^{\prime \prime}\right)$-span $25.4 \mathrm{~mm}$-width, and $6.35 \mathrm{~mm}\left(0.25^{\prime \prime}\right)$ indentor.

Fig. 5 - Least-square fit for loading with $n=1.5$ for graphite/epoxy with $101.6 \mathrm{~mm}\left(4^{\prime \prime}\right)$-span, $25.4 \mathrm{~mm}$-width, and $6.35 \mathrm{~mm}\left(0.25^{\prime \prime}\right)$ indentor.

Fig. 6 - Least-square fit for loading with $n=1.5$ for graphite/epoxy with $50.8 \mathrm{~mm}\left(2^{\prime \prime}\right)-\operatorname{span}, 25.4 \mathrm{~mm}\left(1^{\prime \prime}\right)$-width, and $72.7 \mathrm{~mm}\left(0.5^{\prime \prime}\right)$ indentor.

Fig. 7 - Least-square fit for loading with $n=1.5$ for graphite/epoxy wi th $101.6 \mathrm{~mm}\left(4^{\prime \prime}\right)$-span, $25.4 \mathrm{~mm}\left(1^{\prime \prime}\right)$-width, and $12.7 \mathrm{~mm}\left(0.5^{\prime \prime}\right)$ indentor.

Fig. 8 - Unloading curves for glass/epoxy with $q=2.5,50.8 \mathrm{~mm}\left(2^{\prime \prime}\right)$ span and $6.35 \mathrm{~mm}\left(0.25^{\prime \prime}\right)$ indentor.

Fig. 9 - Unloading curves for glass/epoxy with $q=3.0,50.8 \mathrm{~mm}\left(2^{\prime \prime}\right)-$ span, and $6.35 \mathrm{~mm}\left(0.25^{\prime \prime}\right)$ indentor.

Fig. 10 - Unloading curves for glass/epoxy with $50.8 \mathrm{~mm}\left(2^{\prime \prime}\right)$-span and $6.35 \mathrm{~mm}(0.25)$ indentor using area fit.

Fig. 11 - Unloading curves for glass/epoxy with $50.8 \mathrm{~mm}\left(2^{\prime \prime}\right)$-span and $6.35 \mathrm{~mm}\left(0.25^{\prime \prime}\right)$ indentor using $\alpha_{\mathrm{cr}}=0.102 \mathrm{~mm}\left(0.004^{\prime \prime}\right)$.

Fig. 12 - Unloading curves for graphite/epoxy with $50.8 \mathrm{~mm}\left(2^{\prime \prime}\right)$-span, $25.4 \mathrm{~mm}(1 ")$-width and $6.35 \mathrm{~mm}\left(0.25^{\prime \prime}\right)$ indentor using area fit. 
Fig. 13 - Unloading curves for graphite/epoxy with $50.8 \mathrm{~mm}\left(2^{\text {"I }}\right)$-span, $25.4 \mathrm{~mm}\left(\mathrm{l}^{\prime \prime}\right)$-width, and $12.7 \mathrm{~mm}\left(0.5^{\prime \prime}\right)$ indentor using area fit.

Fig. 14 - Unloading curves for graphite/epoxy with $50.8 \mathrm{~mm}\left(2^{\text {" })-s p a n, ~}\right.$ 25. $\left.\mathrm{mm}(]^{\prime \prime}\right)$-width, and $6.35 \mathrm{~mm}\left(0.25^{\prime \prime}\right)$ indentor using $\alpha_{\mathrm{cr}}=$ $0.0803 \cdot \mathrm{mm}\left(0.00316^{\prime \prime}\right)$.

Fig. 15 - Unloading curves for graphite/epoxy with $50.8 \mathrm{~mm}\left(2^{\prime \prime}\right)$-span, $25.4 \mathrm{~mm}(1 ")$-width, and $12.7 \mathrm{~mm}\left(0.5^{\prime \prime}\right)$ indentor using $\alpha_{\mathrm{cr}}=$ $0.0803 \mathrm{~mm}\left(0.00376^{\prime \prime}\right)$.

Fig. 16 - Reloading curves for graphite/epoxy with $50.8 \mathrm{~mm}\left(2^{\prime \prime}\right)$-span and $12.7 \mathrm{~mm}\left(0.5^{\prime \prime}\right)$ indentor.

Fig. 17 - Reloading curves for graphite/epoxy with $101.6 \mathrm{~mm}\left(4^{\prime \prime}\right)$-span and $12.7 \mathrm{~mm}\left(0.5^{\prime \prime}\right)$ indentor. 


\section{NOMENCLATURE}

$D_{S} \quad$ Diameter of the spherical indentor

$E_{1} \quad$ Longitudinal modulus of elasticity

$E_{2} \quad$ Transverse modulus of elasticity

$E_{S} \quad$ Young's modulus for sphere

$E_{t} \quad$ Young's modulus for target

F Contact force

$F_{m} \quad$ Maximum contact force at unloading

$G_{12}$ In-plane shear modulus of elasticity

$R_{S} \quad$ Radius of sphere

$k \quad$ Contact coefficient

$k_{1} \quad$ Reloading coefficient

$k^{\prime} \quad$ Contact coefficient with the unit of stress

s Unloading coefficient

$\alpha^{\cdot} \quad$ Indentation

$\alpha_{0} \quad$ Permanent indentation

${ }^{\alpha} \mathrm{cr} \quad$ Critical indentation

${ }_{m}^{\alpha} \quad$ Maximum identation at unloading

$v_{S}$. Poisson's ratio of sphere

$v_{t} \quad$ Poisson's ratio of target 


\section{Introduction}

It is well recognized that composite laminates are susceptible to damage resulting from impact of foreign objects. In general, hard and soft objects result in different failure modes. If the object is relatively rigid and small, then the contact time is short and extensive damage occurs in the neighborhood of the contact region. The extent of damage obviously depends on the contact force between the object and the target composite. An accurate account of the contact force and indentation is necessary to quantify the impact damage.

Direct measurement of the dynamic contact force is not an easy task due to the wide range of impact velocities and other parameters, and limitations of experimental techniques. The objective of this study is to determine experimentaliy static indentation laws for epoxy-based composite laminates in contact with steel balls and then model them in power laws.

The most famous elastic contact law, $F=k \alpha^{3 / 2}$, was derived by Hertz [1] for the contact of two spheres of elastic isotropic materials based upon theory of elasticity. The contact between a sphere and a half-space is a limiting case. Since this contact law is derived based upon the contact of elastic spheres, one faces several uncertainties when applying it to laminated composites. First, most laminated composites in use can not be adequately represented by a half-space. Second, the anisotropic and nonhomogeneous property of laminated composites may alter the form of the 1aw. Third, the strain rate which is not accounted for by the Hertzian law may have significant effects on the $F$ - a relation. Except for the strain rate effect, the first two uncertainties may be 
cleared by analyzing the exact contact problem of a sphere pressed into a laminated composite by using three-dimensional elasticity. However, experience tells us that analytical solutions for such contact problems are extremely difficult to obtain especially if permanent deformations are to be accounted for during unloading. Since unloading paths are important as far as the local damage zone is concerned, in this study, an experimental approach is taken to determine the law of contact for composites. However, the strain rate effect is neglected.

\section{Hertzian Law of Contact}

When two solid bodies are in contact, deformation takes place in the contact zone and the contact force results. Once the contact force is obtained, conventional methods for stress analysis can be used to find the stress distribution in the bodies. Determination of the contact forceindentation relationship often becomes the most important step in analyzing the contact problem.

A special case of the Hertz contact problem is the contact of an elastic sphere and an elastic half space. The contact force $F$ and the indentation depth a have the relation

$$
F=k a^{3 / 2}
$$

where

$$
k=(4 / 3)\left(R_{s}\right)^{1 / 2}\left[\left(1-v_{s}{ }^{2}\right) / E_{s}+\left(1-v_{t}{ }^{2}\right) / E_{t}\right]^{-1}
$$


In equation (2), $R_{S}$ is the radius of the sphere, $v$ is the Poisson's ratio, $E$ is the Young's modulus, and subscripts $s$ and $t$ indicate the sphere and the target, respectively. Equation (1) is usually called the Hertzian law of contact for a sphere in contact with a half-space.

The 1.5 power given by equation ( 1 ) was found to be valid by willis [2] for a rigid sphere pressed on a transversely isotropic half-space. A modified contact law with

$$
k=(4 / 3)\left(R_{s}\right)^{1 / 2}\left[\left(1-\nu_{s}^{2}\right) / E_{s}+1 / E_{2}\right]^{-1}
$$

was employed by Sun [3] for a study on impact of laminated composites. In equation (3), $R_{s}, \nu_{s}$ and $E_{s}$ are the radius, the Poisson's ratio and the Young's modulus of the isotropic sphere, respectively, and $E_{2}$ is the modulus of elasticity transverse to the fiber-direction in the fiber-reinforced composite.

A more general form for the contact law was proposed by Meyer [4] as

$$
F=k \alpha^{n}
$$

which has been found suitable for many static indentations. It is obvious that when $n=1.5$ and $k$ given by equation (2) this relation reduces to the Hertzian law for isotropic bodies.

Permanent indentation in composite targets often takes place even at relatively low loading levels. Thus, the aforementioned indentation laws for elastic bodies are valid only for the loading process. To account for the permanent deformation, the following power law was suggested by crook [5]. 


$$
F=F_{m}\left[\left(\alpha-\alpha_{0}\right) /\left(\alpha_{m}-\alpha_{0}\right)\right]^{q}
$$

where $F_{m}$ is the maximum contact force just before unloading, $\alpha_{m}$ is the indentation corresponding to $F_{m}$, and $\alpha_{0}$ is the permanent indentation during this loading-unloading cycle. This unloading law was used by Barnhart and Goldsmith [6] for impact of a steel ball onto an armor plate.

\section{Experimental Procedures}

The experimental set-up is shown schematically in Fig. 1. The indentation was measured by a dial gage that permits reading up to $7 / 5000$ in. The dial gage was mounted on a ' $C$ ' bracket fixed to the loading piston so that only the relative displacement between the indentor and the beam was recorded. The load applied pneumatically was measured using a load cell and a strain indicator. Two steel balls of diameters $6.35 \mathrm{~mm}$ $\left(0.25^{\prime \prime}\right)$ and $12.7 \mathrm{~mm}\left(0.5^{\prime \prime}\right)$ were used as indentors. In all tests the beam was clamped at both ends.

Two types of laminated composites have been tested, namely glass/epoxy and graphite/epoxy. The glass/epoxy was Scotch Ply 1002 by the 3M Company. It contained $100^{\circ}$-plies and $990^{\circ}$-plies which alternate in the layup with one $0^{\circ}-$ ply on top and on at the bottom. The thickness of the beam was $4.83 \mathrm{~mm}\left(0.19^{\prime \prime}\right)$ and the width $38.1 \mathrm{~mm}\left(1.5^{\prime \prime}\right)$. The graphite/epoxy specimens were $[0 / 45 / 0 /-45 / 0]_{2 \mathrm{~s}}$ laminates. The thickness was $2.54 \mathrm{~mm}(0.1 \mathrm{in.})$. Two specimen widths were considered, namely $25.4 \mathrm{~mm}$ (1.0 in.) and $38.1 \mathrm{~mm}$ (1.5 in.). Their material properties are given as follows: 
Glass/Epoxy:

$$
\begin{aligned}
E_{1} & =39.3 \mathrm{GPa}\left(5.7 \times 10^{6} \mathrm{psi}\right) \\
E_{2} & =8.27 \mathrm{GPa}\left(1.2 \times 10^{6} \mathrm{psi}\right) \\
\mathrm{G}_{12} & =4.14 \mathrm{GPa}\left(0.6 \times 10^{6} \mathrm{psi}\right) \\
v_{12} & =0.26
\end{aligned}
$$

Graphite/Epoxy:

$$
\begin{aligned}
E_{1} & =120.7 \mathrm{GPa}\left(17.5 \times 10^{6} \mathrm{psi}\right) \\
E_{2} & =7.93 \mathrm{GPa}\left(1.15 \times 10^{6} \mathrm{psi}\right) \\
G_{12} & =5.52 \mathrm{GPa}\left(0.80 \times 10^{6} \mathrm{psi}\right) \\
v_{12} & =0.30
\end{aligned}
$$

where subscripts 1 and 2 indicate directions parallel and perpendicular to the fiber, respectively.

Data were recorded in steps of about 2 to 5 units in the dial gage. Readings on the dial gage and strain indicator were taken about 10 to 20 seconds after the load was increased by one step.

4 Experimental Results and Modeling

\subsection{Loading Curve}

(A) Glass/Epoxy

For the glass/epoxy laminate, three sets of loading data were obtained for each span with a $6.35 \mathrm{~mm}\left(0.25^{\prime \prime}\right)$ diameter indentor. These data were used to determine the best fit for the power law, equation (4), using the least square method. A typical set of the data is presented in Fig. 2. The power indexes 
for all three cases appear to be rather close to that of the classical Hertzian law for isotropic solids, i.e., $n=1.5$. For this reason, we set $n=1.5$, and then determined the contact coefficient $k$ by using the least square fit. One of the resulting curves is shown in Fig. 3 . The curves seem to fit the data very well also.

Table 1 summarizes the indentation law (the loading portion) obtained from the experimental data for the glass/epoxy laminate. It is interesting to note that with $n=1.5$, the values of $k$ for different spans are almost a constant. This may be taken as an indication that the indentation law is independent of span. In other words, the bending stress in the range of these experiments does not influence the contact rigidity.

In Table 1, the modified Hertzian law, equation (3), is also presented using the material constants given in equation (6). It is found that the value of $k$ is higher than the experimental values. However, it does provide a good estimate of the contact behavior.

\section{(B) Graphite/Epoxy}

For the $6.35 \mathrm{~mm}\left(0.25^{\prime \prime}\right)$ diameter indentor, three sets of data were obtained for each span, while for the $12.7 \mathrm{~mm}\left(0.5^{\prime \prime}\right)$ diameter indentor, except for one case, two sets of data were collected. The value of $n$ was set equal to $7: 5$. The values of $k$ fitted using each set of unloading data and all three (or two) sets of data are presented in Table 2. The corresponding modified Hertzian law are also shown in Table 2 for comparison. In Figs. 4-7 four typical sets of the experimental data are compared with the loading curves predicted by the power law. 
From the values of $k$ for the two indentors, it was found that $k$ for $12.7 \mathrm{~mm}\left(0.5^{\prime \prime}\right)$ indentor is about 1.8 times larger than that for the $6.35 \mathrm{~mm}$ $\left(0.25^{\prime \prime}\right)$ indentor. According to the Hertzian law, $k$ is proportional to the square root of the diameter of the indentor and the increase in the $k$ value should be 1.414 .

From the experimental results, it is difficult to assess the effect of the specimen width. However, the variation in $\mathrm{k}$ for the $12.7 \mathrm{~mm}\left(0.5^{\prime \prime}\right)$ indentor with respect to span and width seem to be smaller than that for the $6.37 \mathrm{~mm}\left(0.25^{\prime \prime}\right)$ indentor.

\subsection{Unloading Curve}

(A) Glass/Epoxy

From the test results we observed that permanent deformation occurred after an indentation test at very low load levels. The unloading paths were very different from the loading path as can be seen from Fig. 8. The unloading curves were modeted by using equation (5) in which $q$ and $\alpha_{0}$ were determined from experimental data. Since the permanent indentation $\alpha_{0}$ was difficult to measure, the whole set of data for each unloading was taken to determine $q$ and $\alpha_{0}$ by the least square method. The results showed that the values of $q$ thus obtained varied between 2.0 and 3.0. It was found that $q$ increased as the loading level increased. For $q=3.0$ and $q=2.5$, equation (5) seems to fit the overall data quite well as shown by Figs. 8-9. However, if $q=3.0$, the value of $\alpha_{0}$ might become negative in some cases. For this reason, $q=2.5$ was chosen.

It should be pointed out that the value of $\alpha_{0}$ obtained in this manner may not be the true permanent indentation. It is a value which can make 
the power law given by equation (5) fit the total data in an unloading path.

Since $\alpha_{0}$ depends on where the unloading begins, it seems that many unloading tests have to be performed in order that the unloading law given by equation (5) can be useful. In other words, the relation between $\alpha_{0}$ and $F_{m}$ must be established.

Setting $q=2.5$, we rewrite equation (5) in the following form

$$
F=s\left(\alpha-\alpha_{0}\right)^{5 / 2}
$$

where

$$
s=F_{m} /\left(\alpha_{m}-\alpha_{0}\right)^{5 / 2}
$$

is an unloading rigidity. A fitting of the data can be obtained by fixing the value of $s$ in all the unloading paths for finding $\alpha_{0}$. In doing so, we imply that the unloading rigidity s remains unchanged. Such assumption will greatly simplify the modeling of unloading. With this in mind, it is assumed that

$$
k / s=\alpha_{c r}
$$

is a constant for a given material system and size of the indentor. From the loading curve we have

$$
F_{m}=k \alpha_{m}^{3 / 2}
$$

By combining equations (9) through (11) the following equation is obtained 


$$
\alpha_{0} / \alpha_{m}=1-\left(\alpha_{c r} / \alpha_{m}\right)^{2 / 5}
$$

This equation can be used to calculate $\alpha_{0}$ as a function of $\alpha_{m}$.

From equation (12) it is easy to see that

$$
\alpha_{0} \geq 0 \text { as } \alpha_{m} \geq \alpha_{c r}
$$

i.e., when indentation passes the value $\alpha_{c r}$ then permanent deformation occurs. To avoid results which are not physically meaningfur, we set

$$
\alpha_{0}=0 \text { if } \alpha_{m} \leq \alpha_{c r}
$$

Hence, according to this model, ${ }_{c}{ }_{c r}$ can be regarded as the 'yield' point in indentation.

Since the energy dissipation in each loading-unloading cycle is of the main interest in this study, it is sensible to select $\alpha_{0}$ in the unloading law so that the area under the unloading curve is equal to that calculated from the experimental data. One set of the unloading curves predicted by using the unloading law with this "area fit" is presented in Fig. 10. If these values of $\alpha_{0}$ are substituted into equation (9), a range of value for $s$ is obtained. By using the averaged value for $s$, the value for $\alpha_{c r}$ is obtained from equation (10) as following

$$
\alpha_{c r}=10.15 \times 10^{-2} \mathrm{~mm}\left(4.0 \times 10^{-3} \text { inch }\right)
$$

The corresponding $\alpha_{0}$ can then be obtained from equation (12). The unloading curves corresponding to those shown in Fig. 10 using this $\alpha_{\mathrm{cr}}$ are shown in Fig. 11. These curves seem to yield good agreement with experimental data. It was noted that a small variation in $\alpha_{\mathrm{cr}}$ would not have any appreciable effect on the unloading curve. 
Table 3 summarizes the comparison of the areas under the unloading curves predicted by the direct area fit and the use of $\alpha_{\mathrm{cr}}$. The values of $\alpha_{0}$ obtained from the two approaches are also listed for comparison. The approach using $\alpha_{\mathrm{cr}}$ is found to be adequate in estimating the area under the unloading curve.

\section{(B) Graphite/Epoxy}

For the graphite/epoxy laminate, again $q=2.5$ was used for the unloading law. Figs. 12-13 show some of the experimental data and the predicted unloading curves using values of $\alpha_{0}$ obtained by matching the area under the unloading curve.

The best value of $\alpha_{\mathrm{cr}}$ for graphite/epoxy was found to be

$$
\alpha_{\mathrm{cr}}=8.03 \times 10^{-2} \mathrm{~mm}\left(3.16 \times 10^{-3} \text { inch }\right)
$$

for both sizes of indentor. The unloading curves predicted by using this $\alpha_{\mathrm{cr}}$ value corresponding to the cases presented in Figs. 12-13 are presented in Figs. 14-15. Excellent agreement with experimental results was noted. The results for the $6.25 \mathrm{~mm}\left(0.2^{\prime \prime}\right)$ and $12.7 \mathrm{~mm}\left(0.5^{\prime \prime}\right)$ indentors obtained according to the above two approaches are summarized in Table 4 and Table 5, respectively. Note that the loading curves in Figs. 12-15 were plotted using a particular set of loading data for each case rather than the average value.

The fact that $\alpha_{c r}$ is not dependent on the indentor size is interesting. This may imply that $\alpha_{\mathrm{cr}}$ is a material property similar to the yield stress for mild steel. 


\subsection{Reloading Curve}

In the case where multiple impacts occur, the reloading behavior must be modeled. The reloading experiment was performed only on the graphite/epoxy laminate with the $1.27 \mathrm{~cm}\left(0.5^{\prime \prime}\right)$ diameter indentor.

The reloading law was assumed to be in the form

$$
F=k_{1}\left(\alpha-\alpha_{0}\right)^{p}
$$

where $k_{1}$ is a reloading rigidity. From the experimental data, $p=1.5$ seemed to have fitted the data best.

It was observed that when the loading level was not too high, then the reloading curve always returned to where the unloading began. If such condition is imposed on the reloading law given by equation (16), then we have

$$
k_{1}=F_{m} /\left(\alpha_{m}-\alpha_{0}\right)^{3 / 2}
$$

Thus the reloading rigidity $k_{1}$ is determined if the unloading condition $\left(F_{m}, \alpha_{m}\right.$, and $\left.\alpha_{0}\right)$ is specified. In other words, there is no need to perform reloading experiments to find the reloading rigidity $k_{1}$.

Figs. 16-17 show typical experimental data and the predicted reloading curves obtained according to equations (16-17). Good agreement is noted.

Table 6 shows a number of values of $k_{1}$ computed according to equation (17). It is seen that these values are quite close to the loading rigidity $k$ for small $\alpha_{0}$. However, for higher loading levels, a substantial deviation exists between these two values. 


\section{Discussion}

From the results for the graphite/epoxy laminate, some scatter in the value of $k$ in the loading law is noted even when the same material properties, indentor, and loading condition are used. This could be attributed to local material nonhomogeneity in the composite.

Being accustomed to the use of stress-strain relation to describe solid material properties one would attempt to modify the loading law into a similar form. A natural step that one would take is to divide the contact force $F$ by a reference area and the indentation $\alpha$ by a reference length. Using the projection of the contact area, $2 \pi D_{S} \alpha$, as the reference area and the critical indentation $\alpha_{c r}$ as the reference length, we obtain from the indentation law the following

$$
F /\left(\pi D_{s} \alpha\right)=\left[k \alpha_{c r}^{1 / 2} /\left(\pi D_{s}\right)\right]\left(\alpha / \alpha_{c r}\right)^{1 / 2}
$$

Such form does not offer any advantage over the original form.

If the reference area $\pi D_{s} \alpha_{c r}$, the projection of the contact area when $\alpha=\alpha_{c r}$, is used instead, then the indentation law can be modified into

$$
F^{\prime}=k^{\prime}\left(\alpha^{\prime}\right)^{3 / 2}
$$

where

$$
\begin{aligned}
& F^{\prime}=F /\left(D_{s} \alpha_{c r}\right) \\
& k^{\prime}=k \alpha_{c r}^{1 / 2} / D_{s} \\
& \alpha^{\prime}=\alpha / \alpha_{c r}
\end{aligned}
$$


Note that $F^{\prime}$ has the unit of stress. Values of $k^{\prime}$ for the graphite/epoxy laminate are summarized in Table 7.

From equation (21), it is evident that $k^{\prime}$ becomes a constant if $k$ is proportional to the diameter of the indentor. From our experimental data for the two indentor sizes, it appears that $k$ is proportional to $\left(D_{S}\right)^{0.85}$ as opposed to $\left(D_{S}\right)^{0.5}$ predicted by the classical Hertzian law. More experimental data from more indentor sizes are needed to establish the relationship between $k$ and the size of indentor.

In summary, we have established loading, unloading and reloading laws for glass/epoxy and graphite/epoxy laminates in contact with steel balls. For loading and reloading, 1.5 power laws seem to fit the data and for unloading, 2.5 power seems adequate. By using the critical indentation, $\alpha_{c r}$, permanent indentations $\alpha_{0}$ can be related to the unloading force $F_{m}$, and consequently only one unloading curve has to be established experimentally. Further, since $\alpha_{\mathrm{cr}}$ seems to depend only on the material properties, only one unloading test needs to be conducted for each material system. For reloading, if equation (16) is employed, no unloading tests are needed to establish the unloading law. 
6. References

[1] Timoshenko, S., Theory of Elasticity, McGraw-Hill, New York, 3rd edition, 1970, pp. 409-420.

[2] Willis, J.R., "Hertzian Contact of Anjsotropic Bodies," Journal of Mechanics and Physics of Solids, Vol. 14, 1966, pp. 163-176.

[3] Sun, C.T., "An Analytical Method for Evaluation of Impact Damage Energy of Laminated Composites," in Composite Materials: Testing and Design (Fourth Conference), ASTM, STP 617, American Society for Testing and Materials, 1977, pp. 427-440.

[4] Goldsmith, W., Impact, Edward Arnold, London, 1960, pp. 82-89.

[5] Crook, A.W., "A Study of Some Impacts Between Metal Bodies by a Piezoelectric Method, "Proceedings of Royal Society, London, A 2?2, 1952 , p. 377.

[6] Barnhart, K.E., and Goldsmith, W., "Stresses in Beams during Transverse Impact," Journal of Applied Mechanics, Vol. 24, 1957, pp. 440-446. 
Acknowledgments

This work was sponsored by NASA-Lewis Research Center under Grant No. NSG3185 with Purdue University. The authors are grateful to Dr. C.C. Chamis of NASA-Lewis Research Center for his valuable suggestions during the course of this research. 
Table 1-Loading law. $F=K \alpha^{n}$ for glass/epoxy with $6.35 \mathrm{~mm}$ diameter indentor, $F$ in $N$ and $\alpha$ in mm ( $F$ in $1 b$ and $\alpha$ in inch):

\begin{tabular}{|c|c|c|c|c|}
\hline \multicolumn{5}{|c|}{ Glass/Epoxy: $\left[(0 / 90)_{4} / 0 / 90 / 0 /(90 / 0)_{4}\right]$} \\
\hline \multicolumn{2}{|c|}{ Span, $\mathrm{mm}$ (in.). } & $50.8(2.0)$ & $101.6(4.0)$ & $152.4(6.0)$ \\
\hline \multirow{2}{*}{$\begin{array}{l}\text { Least } \\
\text { Squares } \\
\text { Fit }\end{array}$} & $n$ & 1.54 & 1.54 & 1.66 \\
\hline & $\begin{array}{l}k, N / \mathrm{mm}^{\mathrm{n}} \\
\left(1 \mathrm{~b} \cdot / \mathrm{in}^{\mathrm{n}}\right)\end{array}$ & $\begin{array}{l}1.70 \times 10^{4} \\
\left(5.57 \times 10^{5}\right)\end{array}$ & $\begin{array}{l}1.71 \times 10^{4} \\
\left(5.60 \times 10^{5}\right)\end{array}$ & $\begin{array}{l}2.00 \times 10^{4} \\
\left(6.55 \times 10^{5}\right)\end{array}$ \\
\hline \multirow{2}{*}{$\begin{array}{l}7.5 \\
\text { Power } \\
\text { Fit }\end{array}$} & $n$ & 1.5 & 1.5 & 1.5 \\
\hline & $\begin{array}{l}\mathrm{k}, \mathrm{N} / \mathrm{mm}^{1.5} \\
\left(1 \mathrm{~b} / \mathrm{in}^{1.5}{ }^{1.5}\right)\end{array}$ & $\begin{array}{l}1.60 \times 10^{4} \\
\left(4.62 \times 10^{5}\right)\end{array}$ & $\begin{array}{l}1.61 \times 10^{4} \\
\left(4.63 \times 10^{5}\right)\end{array}$ & $\begin{array}{l}1.60 \times 10^{4} \\
\left(4.59 \times 10^{5}\right)\end{array}$ \\
\hline $\begin{array}{c}\text { Modified } \\
\text { Hertzian } \\
\text { Law, Eq. } \\
\text { (3) }\end{array}$ & \multicolumn{4}{|c|}{$\begin{array}{l}F=1.90 \times 10^{4}{ }^{1.5}, F \text { in } N, \alpha \text { in mm } \\
\left(F=5.46 \times 10^{5} \alpha, 1.5, F \text { in } 1 \mathrm{~b}, \alpha \text { in inch }\right) \\
E_{S}=207 \mathrm{GPa}\left(30 \times 10^{6} \mathrm{psi}\right), \nu_{S}=0.3 \\
E_{2}=8.27 \mathrm{GPa}\left(1.2 \times 10^{6} \mathrm{psi}\right), R_{S}=3.175 \mathrm{~mm}(0.125 \mathrm{in})\end{array}$} \\
\hline
\end{tabular}


Table 2-Loading law $F=k \alpha{ }^{1.5}$ for $[0 / 45 / 0 /-45 / 0]_{2 s}$ graphite/epoxy; $F$ in $N$ and $\alpha$ in mm (F in ib and $\alpha$ in inch).

\begin{tabular}{|c|c|c|c|c|c|c|c|c|}
\hline Ball Dia., mm (in.) & \multicolumn{4}{|c|}{$6.35(0.25)$} & \multicolumn{4}{|c|}{$12.7(0.50)$} \\
\hline Span, mm (in.) & \multicolumn{2}{|c|}{$50.8(2.0)$} & \multicolumn{2}{|c|}{$101.6(4.0)$} & \multicolumn{2}{|c|}{$50.8(2.0)$} & \multicolumn{2}{|c|}{$101.6(4.0)$} \\
\hline Width, $\mathrm{mm}$ (in.) & $25.4(1.0)$ & $38.1(1.5)$ & $25.4(1.0)$ & $38 . i(1.5)$ & $25.4(1.0)$ & $38.1(1.5)$ & $25.4(1.0)$ & $38.1(1.5)$ \\
\hline$k$, & $\begin{array}{l}2.00 \\
(5.77) \\
\end{array}$ & $\begin{array}{l}1.82 \\
(5.23) \\
\end{array}$ & $\begin{array}{l}1.78 \\
(5.14) \\
\end{array}$ & $\begin{array}{l}2.14 \\
(6.17) \\
\end{array}$ & $\begin{array}{l}3.30 \\
(9.51) \\
\end{array}$ & $\begin{array}{l}3.36 \\
(9.67) \\
\end{array}$ & $\begin{array}{l}3.33 \\
(9.59) \\
\end{array}$ & $\begin{array}{l}3.68 \\
(10.59) \\
\end{array}$ \\
\hline $\begin{array}{l}10^{4} \mathrm{~N} / \mathrm{mm}^{1.5} \\
\left(10^{5} \mathrm{lb} / \mathrm{in}^{1.5}\right)\end{array}$ & $\begin{array}{l}2.13 \\
(6.13) \\
\end{array}$ & $\begin{array}{l}1.83 \\
(5.27) \\
\end{array}$ & $\begin{array}{l}1.82 \\
(5.23) \\
\end{array}$ & $\begin{array}{l}2.20 \\
(6.34) \\
\end{array}$ & $\begin{array}{l}3.59 \\
(10.33) \\
\end{array}$ & $\begin{array}{l}3.31 \\
(9.53) \\
\end{array}$ & $\begin{array}{l}3.18 \\
(9.15) \\
\end{array}$ & $\begin{array}{l}3.48 \\
(10.01) \\
\end{array}$ \\
\hline & $\begin{array}{l}2.06 \\
(5.92)\end{array}$ & $\begin{array}{l}1.85 \\
(5.33)\end{array}$ & $\begin{array}{l}1.83 \\
(5.28)\end{array}$ & $\begin{array}{l}2.32 \\
(6.68)\end{array}$ & $\begin{array}{l}3.56 \\
(10.24)\end{array}$ & & & \\
\hline $\begin{array}{l}k \text {, Group Fit } \\
10^{4} \mathrm{~N} / \mathrm{mm}^{1.5} \\
\left(10^{5} \mathrm{lb} / \text { in. }^{1.5}\right)\end{array}$ & $\begin{array}{l}2.06 \\
(5.94)\end{array}$ & $\begin{array}{l}1.85 \\
(5.33)\end{array}$ & $\begin{array}{l}1.81 \\
(5.22)\end{array}$ & $\begin{array}{l}2.19 \\
(6.29)\end{array}$ & $\begin{array}{c}3.47 \\
(9.98)\end{array}$ & $\begin{array}{l}3.34 \\
(9.62)\end{array}$ & $\begin{array}{l}3.23 \\
(9.30)\end{array}$ & $\begin{array}{l}3.60 \\
(10.37)\end{array}$ \\
\hline $\begin{array}{l}\text { Modified } \\
\text { Hertzian } \\
\text { Law, Ea. (3) }\end{array}$ & \multicolumn{4}{|c|}{$\begin{array}{l}F=1.82 \times 10^{4} \alpha^{1.5} \\
\left(F=5.24 \times 10^{5} \alpha^{1.5}\right) \\
E_{s}=207 \mathrm{GPa}(30 \times 10\end{array}$} & \multicolumn{4}{|c|}{$\begin{array}{c}F=2.57 \times 10^{4} \alpha^{1.5} \\
\left(F=7.41 \times 10^{5} \alpha^{1.5}\right) \\
7.93 \mathrm{GPa}\left(1.15 \times 10^{6} \mathrm{psi}\right)\end{array}$} \\
\hline
\end{tabular}


Table 3-Values of $\alpha_{0}$ and area under the unloading curve by different fits for glass/enoxy

\begin{tabular}{|c|c|c|c|c|c|c|c|c|c|c|c|c|c|}
\hline \multirow{2}{*}{\multicolumn{2}{|c|}{$\begin{array}{l}\text { Soan. } m \text { m (in.) } \\
\mathrm{k}, \mathrm{N} / \mathrm{mm} \mathrm{m}^{1.5}\left(\mathrm{lb} / \mathrm{in}^{1.5}\right)\end{array}$}} & \multicolumn{4}{|c|}{$50.8(2.0)$} & \multicolumn{4}{|c|}{$101.6(4.0)$} & \multicolumn{4}{|c|}{$152.4(6.0)$} \\
\hline & & 1.60 & $\times 10^{4}$ & $4.62 \times 1$ & & 1.61 & $\times 10^{4}(4$ & $63 \times 10^{5}$ & & 1.60 & $\times 10^{4}$ & $1.59 \times 1$ & \\
\hline \multicolumn{2}{|l|}{$\begin{array}{r}F_{m}, \quad N \\
(1 b) \\
\end{array}$} & $\begin{array}{l}529 \\
(119) \\
\end{array}$ & $\left\{\begin{array}{l}842 \\
(189)\end{array}\right.$ & $\begin{array}{l}1513 \\
(340)\end{array}$ & $\begin{array}{l}2206 \\
(496)\end{array}$ & $\begin{array}{l}460 \\
(103)\end{array}$ & $\begin{array}{l}1362 \\
(306)\end{array}$ & $\begin{array}{l}1964 \\
(442) \\
\end{array}$ & $\begin{array}{l}3104 \\
(698) \\
\end{array}$ & $\begin{array}{l}518 \\
(116)\end{array}$ & $\begin{array}{l}1016 \\
(228)\end{array}$ & $\begin{array}{l}1594 \\
(358)\end{array}$ & $\begin{array}{l}2037 \\
(458)\end{array}$ \\
\hline \multicolumn{2}{|c|}{$\begin{array}{l}\alpha_{m}, 10^{-2} m \\
\left(10^{-3} \text { in. }\right)\end{array}$} & $\begin{array}{l}10.3 \\
(4.05) \\
\end{array}$ & $\begin{array}{l}14.0 \\
(5.52)\end{array}$ & $\begin{array}{l}20.7 \\
(8.16) \\
\end{array}$ & $\begin{array}{l}26.6 \\
(10.5) \\
\end{array}$ & $\begin{array}{l}9.40 \\
(3.69) \\
\end{array}$ & $\begin{array}{l}19.3 \\
(7.59) \\
\end{array}$ & $\begin{array}{l}24.6 \\
(9.69) \\
\end{array}$ & $\begin{array}{l}30.1 \\
(11.9) \\
\end{array}$ & $\begin{array}{l}10.2 \\
(4.01) \\
\end{array}$ & $\begin{array}{l}16.0 \\
(6.28) \\
\end{array}$ & $\begin{array}{l}21.5 \\
(8.48) \\
\end{array}$ & $\begin{array}{l}25.3 \\
(9.98) \\
\end{array}$ \\
\hline \multirow{2}{*}{$\begin{array}{r}\alpha_{0}, 10^{-2} \mathrm{~nm} \\
\left(10^{-3} \mathrm{in.}\right)\end{array}$} & $\begin{array}{l}\text { Area } \\
\text { Fit }\end{array}$ & $\begin{array}{l}1.24 \\
(0.49) \\
\end{array}$ & $\begin{array}{l}3.38 \\
(1.33)\end{array}$ & $\begin{array}{l}4.27 \\
(1.68)\end{array}$ & $\begin{array}{l}7.70 \\
(3.03)\end{array}$ & $\begin{array}{l}0.30 \\
(0.12)\end{array}$ & $\begin{array}{l}3.12 \\
(1.23)\end{array}$ & $\begin{array}{l}6.71 \\
(2.64)\end{array}$ & $\begin{array}{l}9.42 \\
(3.71)\end{array}$ & $\begin{array}{l}1.17 \\
(0.46)\end{array}$ & $\begin{array}{l}2.49 \\
(0.98)\end{array}$ & $\begin{array}{l}6.53 \\
(2.57)\end{array}$ & $\begin{array}{l}8.69 \\
(3.42)\end{array}$ \\
\hline & $\begin{array}{l}a_{c r} \\
F i t\end{array}$ & $\begin{array}{l}0.56 \\
(0.22) \\
\end{array}$ & $\begin{array}{l}1.70 \\
(0.67) \\
\end{array}$ & $\begin{array}{l}5.13 \\
(2.02) \\
\end{array}$ & $\begin{array}{l}8.53 \\
(3.36) \\
\end{array}$ & $\begin{array}{l}0.0 \\
(0.0) \\
\end{array}$ & $\begin{array}{l}4.37 \\
(1.72) \\
\end{array}$ & $\begin{array}{l}7.34 \\
(2.89) \\
\end{array}$ & $\begin{array}{l}10.6 \\
(4.18) \\
\end{array}$ & $\begin{array}{l}0.0 \\
(0.0) \\
\end{array}$ & $\begin{array}{l}2.64 \\
(1.04) \\
\end{array}$ & $\begin{array}{l}5.59 \\
(2.20) \\
\end{array}$ & $\begin{array}{l}7.77 \\
(3.06 \\
\end{array}$ \\
\hline \multirow{2}{*}{$\begin{array}{l}\text { Area, } \\
10^{-2} \mathrm{~mm}-\mathrm{N} \\
\left(10^{-4} \text { in. }-1 \mathrm{~b}\right)\end{array}$} & $\begin{array}{l}\text { Area } \\
\text { Fit }\end{array}$ & $\begin{array}{l}137 \\
(121)\end{array}$ & $\begin{array}{l}256 \\
(227)\end{array}$ & $\begin{array}{l}712 \\
(630)\end{array}$ & $\begin{array}{l}1194 \\
(1057)\end{array}$ & $\begin{array}{l}119 \\
(105)\end{array}$ & $\begin{array}{l}628 \\
(556)\end{array}$ & $\begin{array}{l}1016 \\
(890)\end{array}$ & $\begin{array}{l}1570 \\
(1390)\end{array}$ & $\begin{array}{l}133 \\
(118)\end{array}$ & $\begin{array}{l}390 \\
(346)\end{array}$ & $\begin{array}{l}683 \\
(605)\end{array}$ & $\begin{array}{l}970 \\
(859)\end{array}$ \\
\hline & $\begin{array}{l}{ }^{a_{c r}} \\
\text { Fit }\end{array}$ & $\begin{array}{l}155 \\
(137)\end{array}$ & $\begin{array}{l}296 \\
(262)\end{array}$ & $\begin{array}{l}674 \\
(596)\end{array}$ & $\begin{array}{l}1142 \\
(1011)\end{array}$ & $\begin{array}{l}123 \\
(109)\end{array}$ & $\begin{array}{l}581 \\
(514)\end{array}$ & $\begin{array}{l}969 \\
(858)\end{array}$ & $\begin{array}{l}1481 \\
(1311)\end{array}$ & $\begin{array}{l}150 \\
(133)\end{array}$ & $\begin{array}{l}387 \\
(342)\end{array}$ & $\begin{array}{l}726 \\
(643)\end{array}$ & $\begin{array}{l}1024 \\
(906)\end{array}$ \\
\hline
\end{tabular}


Table 4-Values of $\alpha$ and area under unloading curve by different fits for graphite/epoxy with $6.35 \mathrm{~mm}\left(0.25 \mathrm{in}, \mathrm{t}^{0}\right.$ indentor

\begin{tabular}{|c|c|c|c|c|c|c|c|c|c|c|c|c|c|}
\hline \multirow{2}{*}{\multicolumn{2}{|c|}{$\frac{\text { Span, mm (in.) }}{\text { Width, mm (in.) }}$}} & \multicolumn{6}{|c|}{$50.8(2.0)$} & \multicolumn{6}{|c|}{$101.6(4.0)$} \\
\hline & & \multicolumn{3}{|c|}{$25.4(1.0)$} & \multicolumn{3}{|c|}{$38.1(1.5)$} & \multicolumn{3}{|c|}{$25.4(1.0)$} & \multicolumn{3}{|c|}{$38.1(1.5)$} \\
\hline \multicolumn{2}{|c|}{$k, N / m m^{1.5}\left(1 \mathrm{~b} / \mathrm{in}^{1.5}\right)$} & \multicolumn{3}{|c|}{$2.06 \times 10^{4}\left(5.92 \times 10^{5}\right)$} & \multicolumn{3}{|c|}{$1.85 \times 10^{4}\left(5.33 \times 10^{5}\right)$} & \multicolumn{3}{|c|}{$1.83 \times 10^{4}\left(5.28 \times 10^{5}\right)$} & \multicolumn{3}{|c|}{$2.32 \times 10^{4}\left(6.68 \times 10^{5}\right)$} \\
\hline \multicolumn{2}{|c|}{$\begin{array}{ll}F_{m}, & N \\
(1 b) \\
\end{array}$} & $\begin{array}{l}668 \\
(150) \\
\end{array}$ & $\begin{array}{l}934 \\
(210) \\
\end{array}$ & $\begin{array}{l}1223 \\
(275) \\
\end{array}$ & $\begin{array}{l}273 \\
(61.3) \\
\end{array}$ & $\begin{array}{l}561 \\
(126) \\
\end{array}$ & $\begin{array}{l}997 \\
(224) \\
\end{array}$ & $\begin{array}{l}408 \\
(91.7) \\
\end{array}$ & $\begin{array}{l}612 \\
(138) \\
\end{array}$ & $\begin{array}{l}844 \\
(190)\end{array}$ & $\begin{array}{l}277 \\
(62.3) \\
\end{array}$ & $\begin{array}{l}662 \\
(149) \\
\end{array}$ & $\begin{array}{l}1210 \\
(272) \\
\end{array}$ \\
\hline \multicolumn{2}{|c|}{ 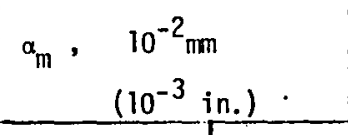 } & $\begin{array}{l}10.2 \\
(4.01) \\
\end{array}$ & $\begin{array}{l}12.7 \\
(5.01) \\
\end{array}$ & $\begin{array}{l}15.2 \\
(6.00) \\
\end{array}$ & $\begin{array}{l}6.00 \\
(2.37) \\
\end{array}$ & $\begin{array}{l}9.70 \\
(3.83) \\
\end{array}$ & $\begin{array}{l}14.2 \\
(5.61) \\
\end{array}$ & $\begin{array}{l}7.90 \\
(3.12) \\
\end{array}$ & $\begin{array}{l}10.4 \\
(4.08) \\
\end{array}$ & $\begin{array}{l}12.9 \\
(5.06)\end{array}$ & $\begin{array}{l}5.20 \\
(2.06) \\
\end{array}$ & $\begin{array}{l}9.30 \\
(3.68)\end{array}$ & $\begin{array}{l}14.0 \\
(5.50) \\
\end{array}$ \\
\hline \multirow{2}{*}{$\begin{array}{r}\alpha_{0}, 10^{-2} \mathrm{~mm} \\
\left(10^{-3} \text { in. }\right)\end{array}$} & $\begin{array}{l}\text { Area } \\
\text { Fit }\end{array}$ & $\begin{array}{l}0.94 \\
(0.37)\end{array}$ & $\begin{array}{l}1.80 \\
(0.71)\end{array}$ & $\begin{array}{l}2.79 \\
(1.10)\end{array}$ & $\begin{array}{l}0.05 \\
(0.02)\end{array}$ & $\begin{array}{l}0.43 \\
(0.17)\end{array}$ & $\begin{array}{l}2.13 \\
(0.84)\end{array}$ & $\begin{array}{l}0.00 \\
(0.00)\end{array}$ & $\begin{array}{l}0.41 \\
(0.16)\end{array}$ & $\left\{\begin{array}{l}1.55 \\
(0.61)\end{array}\right.$ & $\begin{array}{l}0.00 \\
(0.00)\end{array}$ & $\mid \begin{array}{l}0.61 \\
(0.24)\end{array}$ & $\begin{array}{l}1.85 \\
(0.73)\end{array}$ \\
\hline & $\begin{array}{l}{ }^{a} \mathrm{cr} \\
\text { Fit }\end{array}$ & $\begin{array}{l}0.91 \\
(0.36) \\
\end{array}$ & $\begin{array}{l}2.13 \\
(0.84) \\
\end{array}$ & $\begin{array}{l}3.45 \\
(1.36) \\
\end{array}$ & $\begin{array}{l}0.00 \\
(0.00) \\
\end{array}$ & $\begin{array}{l}0.71 \\
(0.28) \\
\end{array}$ & $\begin{array}{l}2.92 \\
(1.15) \\
\end{array}$ & $\begin{array}{l}0.00 \\
(0.00) \\
\end{array}$ & $\begin{array}{l}1.02 \\
(0.40) \\
\end{array}$ & $\left\{\begin{array}{l}2.21 \\
(0.87)\end{array}\right.$ & $\begin{array}{l}0.00 \\
(0.00) \\
\end{array}$ & $\begin{array}{l}0.56 \\
(0.22) \\
\end{array}$ & $\begin{array}{l}2.77 \\
11.09 \\
\end{array}$ \\
\hline \multirow{2}{*}{$\begin{array}{l}\text { Area } \\
10^{-2} \mathrm{~mm}-\mathrm{N} \\
\left(10^{-4} \text { in. }-1 b\right)\end{array}$} & $\begin{array}{l}\text { Area } \\
\text { Fit }\end{array}$ & $\begin{array}{l}188 \\
(166) \\
\end{array}$ & $\begin{array}{l}291 \\
(258) \\
\end{array}$ & $\begin{array}{l}435 \\
(385) \\
\end{array}$ & $\begin{array}{l}46.5 \\
(41.2) \\
\end{array}$ & $\begin{array}{l}149 \\
(132)\end{array}$ & $\begin{array}{l}345 \\
(305)\end{array}$ & $\begin{array}{l}92.2 \\
(81.6)\end{array}$ & $\begin{array}{l}174 \\
(154) \\
\end{array}$ & $\begin{array}{l}272 \\
(241)\end{array}$ & $\begin{array}{l}41.4 \\
(36.7)\end{array}$ & $\begin{array}{l}165 \\
(146)\end{array}$ & $\begin{array}{l}418 \\
(370) \\
\end{array}$ \\
\hline & $\begin{array}{l}\alpha_{c r} \\
\text { Fit }\end{array}$ & $\begin{array}{l}177 \\
(156)\end{array}$ & $\begin{array}{l}282 \\
(250)\end{array}$ & $\begin{array}{l}412 \\
(365)\end{array}$ & $\begin{array}{l}46.9 \\
(41.5)\end{array}$ & $\begin{array}{l}144 \\
(128)\end{array}$ & $\begin{array}{l}323 \\
(286)\end{array}$ & $\begin{array}{l}92.2 \\
(81.6)\end{array}$ & $\begin{array}{l}164 \\
(145)\end{array}$ & $\begin{array}{l}257 \\
(227)\end{array}$ & $\begin{array}{l}41.4 \\
(36.7)\end{array}$ & $\begin{array}{l}166 \\
(147)\end{array}$ & $\begin{array}{l}387 \\
(342)\end{array}$ \\
\hline
\end{tabular}


Table 5-Values of $a$ and area under unloading curve by different fits for graphite/epoxy with ${ }^{0} 12.7 \mathrm{~mm}(0.5 \mathrm{in}$ : $)$ indentor

\begin{tabular}{|c|c|c|c|c|c|c|c|c|c|c|c|c|c|}
\hline \multirow{2}{*}{\multicolumn{2}{|c|}{$\begin{array}{l}\text { Span, mm (in.) } \\
\text { Width, mm (in.) }\end{array}$}} & \multicolumn{6}{|c|}{$50.8(2.0)$} & \multicolumn{6}{|c|}{$101.6(4.0)$} \\
\hline & & \multicolumn{3}{|c|}{$25.4(1.0)$} & \multicolumn{3}{|c|}{$38.1 \cdot(1.5)$} & \multicolumn{3}{|c|}{$25.4(1.0)$} & \multicolumn{3}{|c|}{$38.1(1.5)$} \\
\hline \multicolumn{2}{|c|}{$\mathrm{k}, \mathrm{N} / \mathrm{min}^{1.5}\left(\mathrm{lb} / \mathrm{in}^{1.5}\right)$} & \multicolumn{3}{|c|}{$3.56 \times 10^{4}\left(10.24 \times 10^{5}\right)$} & \multicolumn{3}{|c|}{$3.31 \times 10^{4}\left(9.53 \times 10^{5}\right)$} & \multicolumn{3}{|c|}{$3.18 \times 10^{4}\left(9.15 \times 10^{5}\right)$} & \multicolumn{3}{|c|}{$3.60 \times 10^{4}\left(10.37 \times 10^{5}\right)$} \\
\hline$F_{m}$ & N & $\begin{array}{l}425 \\
(95.5)\end{array}$ & $\begin{array}{l}955 \\
(215)\end{array}$ & $\begin{array}{l}1479 . \\
(333)\end{array}$ & $\begin{array}{l}719 \\
(162)\end{array}$ & $\begin{array}{l}1320 \\
(279)\end{array}$ & $\begin{array}{l}1645 \\
(370)\end{array}$ & 227 & $\begin{array}{l}791 \\
\text { (178) }\end{array}$ & $\begin{array}{l}1239 \\
(279)\end{array}$ & $\begin{array}{l}267 \\
(60.1)\end{array}$ & $\begin{array}{l}900 \\
(202)\end{array}$ & $\begin{array}{l}1285 \\
(289)\end{array}$ \\
\hline $\begin{array}{r}10^{-} \\
\left(10^{-3}\right.\end{array}$ & $\begin{array}{l}2 \mathrm{~mm} \\
\text { in). }\end{array}$ & $\begin{array}{l}5.10 \\
(2.01)\end{array}$ & $\begin{array}{l}9.00 \\
(3.53)\end{array}$ & $\begin{array}{l}12.0 \\
(4.73)\end{array}$ & $\begin{array}{l}7.80 \\
(3.07)\end{array}$ & $\begin{array}{l}11.7 \\
(4.60)\end{array}$ & $\begin{array}{l}13.5 \\
(5.32)\end{array}$ & $\begin{array}{l}3.70 \\
(1.46)\end{array}$ & $\begin{array}{l}8.50 \\
(3.35)\end{array}$ & $\begin{array}{l}1.15 \\
(4.53)\end{array}$ & $\begin{array}{l}3.80 \\
(1.50)\end{array}$ & $\begin{array}{l}8.60 \\
(3.37)\end{array}$ & $\begin{array}{l}10.8 \\
(4.27)\end{array}$ \\
\hline$\alpha_{0}, 10^{-2} \mathrm{~mm}$ & $\begin{array}{l}\text { Area } \\
\text { Fit }\end{array}$ & $\begin{array}{l}0.00 \\
(0.00) \\
\end{array}$ & $\begin{array}{l}0.76 \\
(0.30) \\
\end{array}$ & $\begin{array}{l}2.18 \\
(0.86) \\
\end{array}$ & $\begin{array}{l}0.03 \\
(0.01) \\
\end{array}$ & $\begin{array}{l}1.30 \\
(0.51) \\
\end{array}$ & $\begin{array}{l}2.31 \\
(0.91) \\
\end{array}$ & $\begin{array}{l}0.05 \\
(0.02) \\
\end{array}$ & $\begin{array}{l}0.56 \\
(0.22) \\
\end{array}$ & $\begin{array}{l}1.65 \\
(0.65)\end{array}$ & $\begin{array}{l}0.00 \\
(0.00) \\
\end{array}$ & $\begin{array}{l}0.03 \\
(0.01) \\
\end{array}$ & $\begin{array}{l}1.35 \\
(0.53) \\
\end{array}$ \\
\hline$\left(10^{\circ}\right.$ & $\begin{array}{l}{ }^{\alpha} \mathrm{cr} \\
\mathrm{Fit}\end{array}$ & $\begin{array}{l}0.00 \\
(0.00)\end{array}$ & $\begin{array}{l}0.38 \\
(0.15)\end{array}$ & $\begin{array}{l}1.78 \\
(0.70) \\
\end{array}$ & $\begin{array}{l}0.00 \\
(\underline{0.00)}\end{array}$ & $\begin{array}{l}1.68 \\
(0.66)\end{array}$ & $\begin{array}{l}2.51 \\
(0.99)\end{array}$ & $\begin{array}{l}0.00 \\
(0.00)\end{array}$ & $\begin{array}{l}0.20 \\
(0.08) \\
\end{array}$ & $\begin{array}{l}1.55 \\
(0.61)\end{array}$ & $\begin{array}{l}0.00 \\
(0.00) \\
\end{array}$ & $\begin{array}{l}0.20 \\
(0.08) \\
\end{array}$ & $\begin{array}{l}1.22 \\
(0.48) \\
\end{array}$ \\
\hline Area, & $\begin{array}{l}\text { Area } \\
\text { Fit }\end{array}$ & $\begin{array}{l}63.4 \\
(56.1) \\
\end{array}$ & $\begin{array}{l}224 \\
(198) \\
\end{array}$ & $\left\{\begin{array}{l}415 \\
(367)\end{array}\right.$ & $\begin{array}{l}159 \\
(141)\end{array}$ & $\begin{array}{l}392 \\
(347)\end{array}$ & $\begin{array}{l}527 \\
(466) \\
\end{array}$ & $\begin{array}{l}23.7 \\
(20.9)\end{array}$ & $\begin{array}{l}180 \\
(159)\end{array}$ & $\begin{array}{l}349 \\
(309)\end{array}$ & $\begin{array}{l}29.0 \\
(25.7)\end{array}$ & $\begin{array}{l}220 \\
(194)\end{array}$ & $\begin{array}{l}348 \\
(308)\end{array}$ \\
\hline $\begin{array}{l}10^{-2} \mathrm{~nm}-\mathrm{N} \\
\left(10^{-4} \text { in. }-1 \mathrm{~b}\right)\end{array}$ & $\begin{array}{l}a_{c r} \\
\text { Fit }\end{array}$ & $\begin{array}{l}63.4 \\
(56.1)\end{array}$ & $\begin{array}{l}234 \\
(207)\end{array}$ & $\begin{array}{l}432 \\
(382)\end{array}$ & $\begin{array}{l}160 \\
(142)\end{array}$ & $\begin{array}{l}379 \\
(335)\end{array}$ & $\begin{array}{l}516 \\
(457)\end{array}$ & $\begin{array}{l}24.0 \\
(21.2)\end{array}$ & $\begin{array}{l}188 \\
(166)\end{array}$ & $\begin{array}{l}353 \\
(312)\end{array}$ & $\begin{array}{l}29.0 \\
(25.7) \\
\end{array}$ & $\begin{array}{l}214 \\
(190)\end{array}$ & $\begin{array}{l}353 \\
(312) \\
\end{array}$ \\
\hline
\end{tabular}


Table 6-Comparison of loading rigidity $k$ and reloading rigidity $k_{1}$ for graphite/epoxy with $12.7 \mathrm{~mm}\left(0.5^{*} \mathrm{in}_{\text {. }}\right)$ indentor

\begin{tabular}{|c|c|c|c|c|c|c|c|c|c|}
\hline Span, mm (in.) & \multicolumn{3}{|c|}{$50.8(2.0)$} & \multicolumn{6}{|c|}{$101.6(4.0)$} \\
\hline Width, mm (in.) & \multicolumn{3}{|c|}{$25.4(1.0)$} & \multicolumn{3}{|c|}{$25.4(1.0)$} & \multicolumn{3}{|c|}{$38.1(1.5)$} \\
\hline $\mathrm{k}, \mathrm{N} / \mathrm{mm}^{1.5}$ (1b/in. $\left.{ }^{1.5}\right)$ & \multicolumn{3}{|c|}{$3.56 \times 10^{4}\left(10.24 \times 10^{5}\right)$} & \multicolumn{3}{|c|}{$3.18 \times 10^{4}\left(9.15 \times 10^{5}\right)$} & \multicolumn{3}{|c|}{$3.60 \times 10^{4}\left(10.37 \times 10^{5}\right)$} \\
\hline $\begin{array}{l}N \\
(1 b) \\
\end{array}$ & $\begin{array}{l}428 \\
(95) \\
\end{array}$ & $\begin{array}{l}955 \\
(215) \\
\end{array}$ & $\begin{array}{l}1479 \\
(333) \\
\end{array}$ & $\begin{array}{l}227 \\
(51) \\
\end{array}$ & $\begin{array}{l}791 \\
(178)\end{array}$ & $\begin{array}{l}1239 \\
(279) \\
\end{array}$ & $\begin{array}{l}267 \\
(60) \\
\end{array}$ & $\begin{array}{l}900 \\
(202)\end{array}$ & $\begin{array}{l}1285 \\
(289) \\
\end{array}$ \\
\hline $\begin{aligned} \alpha_{m}, & 10^{-2} \mathrm{~mm} \\
& \left(10^{-3} \text { in. }\right)\end{aligned}$ & $\begin{array}{l}5.11 \\
(2.01)\end{array}$ & $\begin{array}{l}8.97 \\
(3.53)\end{array}$ & $\begin{array}{l}12.0 \\
(4.73)\end{array}$ & $\begin{array}{l}3.71 \\
(1.46)\end{array}$ & $\begin{array}{l}8.51 \\
(3.35)\end{array}$ & $\begin{array}{l}11.5 \\
(4.53)\end{array}$ & $\begin{array}{l}3.81 \\
(1.5)\end{array}$ & $\begin{array}{l}8.56 \\
(3.37)\end{array}$ & $\begin{array}{l}10.8 \\
(4.27)\end{array}$ \\
\hline $\begin{array}{l}\alpha_{0}, \quad 10^{-2} \mathrm{~mm} \\
\left(10^{-3} \text { in. }\right)\end{array}$ & $\begin{array}{l}0.0 \\
(0.0)\end{array}$ & $\begin{array}{l}0.76 \\
(0.30)\end{array}$ & $\begin{array}{l}2.18 \\
(0.86)\end{array}$ & $\begin{array}{l}0.05 \\
(0.02)\end{array}$ & $\begin{array}{l}0.56 \\
(0.22)\end{array}$ & $\begin{array}{l}1.65 \\
(0.65)\end{array}$ & $\begin{array}{l}0.0 \\
(0.0)\end{array}$ & $\begin{array}{l}0.25 \\
(0.01)\end{array}$ & $\begin{array}{l}1.35 \\
(0.53)\end{array}$ \\
\hline $\begin{array}{ll} & 10^{4} \mathrm{~N} / \mathrm{mm}^{1.5} \\
\mathrm{k}_{1}, & \left(10^{5} \mathrm{lb} / \mathrm{in}^{1.5}\right)^{1.5}\end{array}$ & $\begin{array}{l}3.68 \\
(10.6)\end{array}$ & $\begin{array}{l}4.06 \\
(17.7)\end{array}$ & $\begin{array}{l}4.80 \\
(13.8)\end{array}$ & $\begin{array}{l}3.24 \\
(9.33)\end{array}$ & $\begin{array}{l}3.53 \\
(10.2)\end{array}$ & $\begin{array}{l}4.07 \\
(11.5)\end{array}$ & $\begin{array}{l}3.59 \\
(10.3)\end{array}$ & $\begin{array}{l}3.61 \\
(10.4)\end{array}$ & $\begin{array}{l}3.67 \\
(10.6)\end{array}$ \\
\hline
\end{tabular}


Table 7-Values of $k$ ' for graphite/epoxy (Equation (19)).

\begin{tabular}{|c|c|c|c|c|c|c|c|c|}
\hline $\begin{array}{l}\text { Ball Diameter } \\
\text { mm }\end{array}$ & \multicolumn{4}{|c|}{$6.35(0.25)$} & \multicolumn{4}{|c|}{$12.7 \quad(0.50)$} \\
\hline Span, $m m$ (in.) & \multicolumn{2}{|c|}{$50.8(2.0)$} & \multicolumn{2}{|c|}{$101.6(4.0)$} & \multicolumn{2}{|c|}{$50.8(2.0)$} & \multicolumn{2}{|c|}{$101.6(4.0)$} \\
\hline Width, $\mathrm{mm}$ & 25.4 & 38.1 & 25.4 & 38.1 & 25.4 & 38.7 & 25.4 & 38.1 \\
\hline (in.) & $(1.0)$ & $(1.5)$ & $(1.0)$ & $(1.5)$ & $(1.0)$ & $(1.5)$ & $(1.0)$ & $(1.5)$ \\
\hline$k^{\prime}, \quad \frac{\mathrm{GPa}}{\left(10^{5} \mathrm{psi}\right)}$ & $\begin{array}{l}0.92 \\
(1.34)\end{array}$ & $\begin{array}{l}0.81 \\
(1.18)\end{array}$ & $\begin{array}{l}0.81 \\
(1.17)\end{array}$ & $\begin{array}{l}0.98 \\
(1.42)\end{array}$ & $\begin{array}{l}0.77 \\
(1.12)\end{array}$ & $\begin{array}{l}0.74 \\
(1.08)\end{array}$ & $\begin{array}{l}0.72 \\
(1.05)\end{array}$ & $\begin{array}{l}0.81 \\
(1.17)\end{array}$ \\
\hline
\end{tabular}




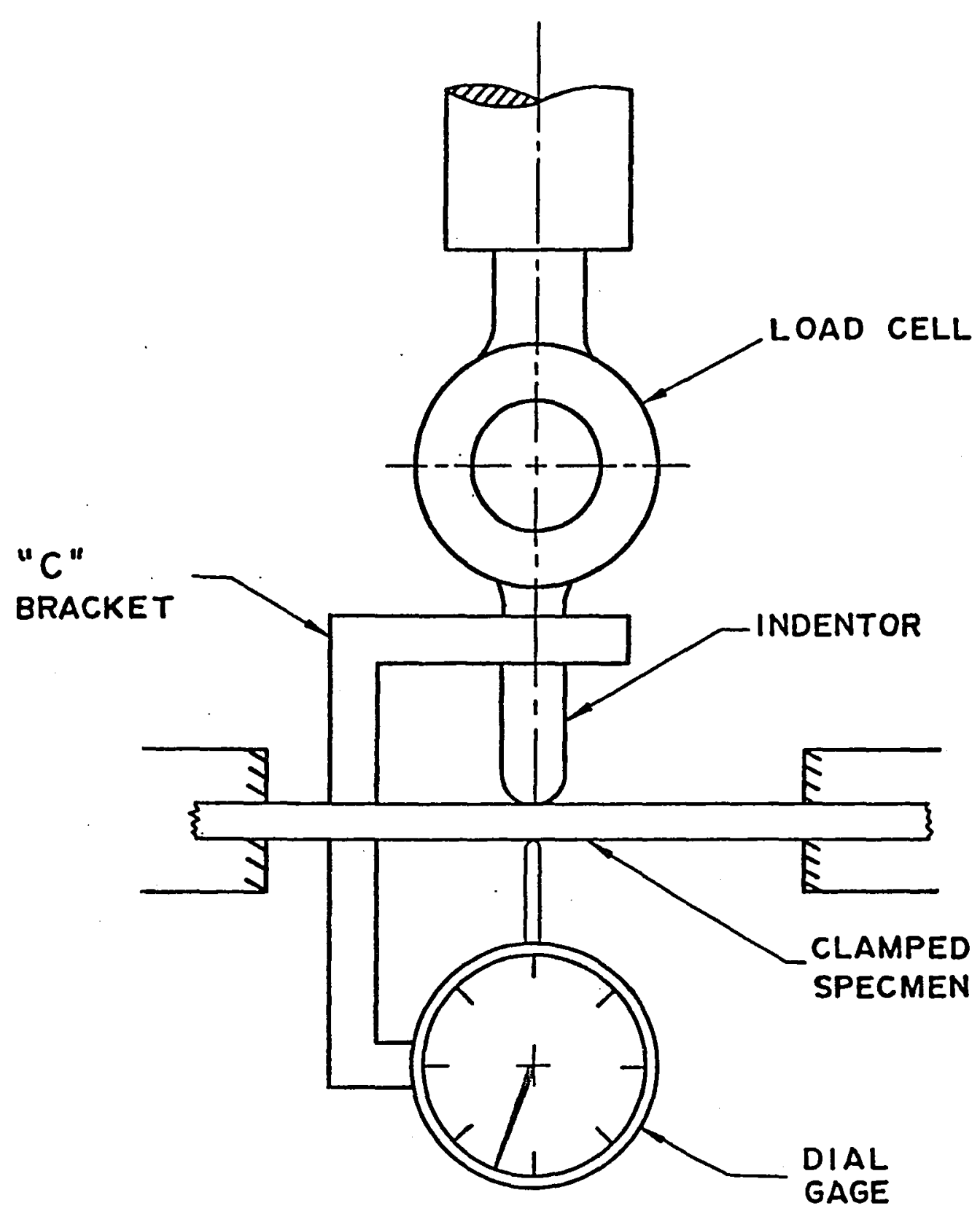

Fig. 1 Indentation test set-up 


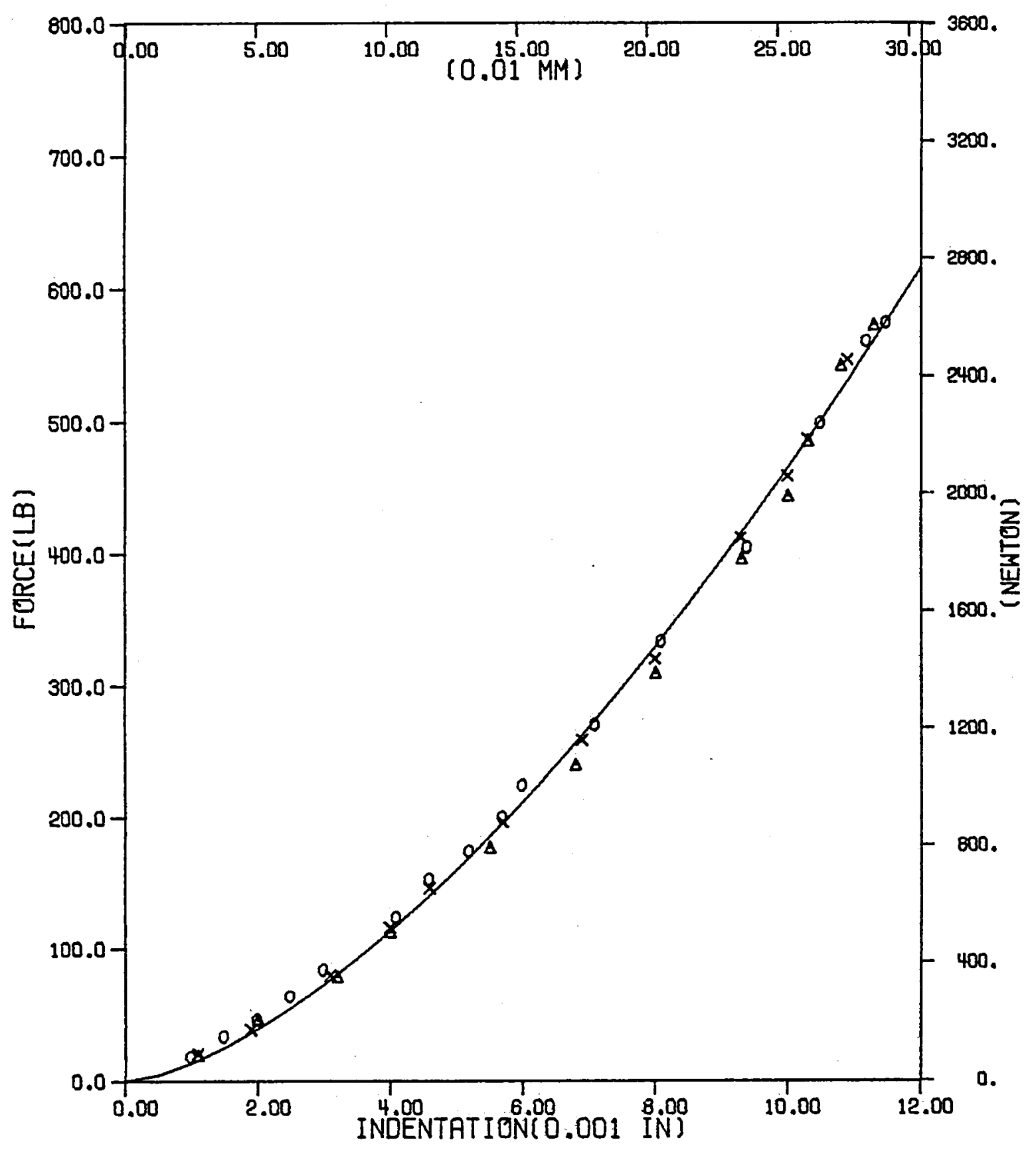

Fig. 2 - Least-square fit for loading for glass/epoxy with $50.8 \mathrm{~mm}\left(2^{\prime \prime}\right)$ span and $6.35 \mathrm{~mm}\left(0.25^{\prime \prime}\right)$ diameter indentor. 


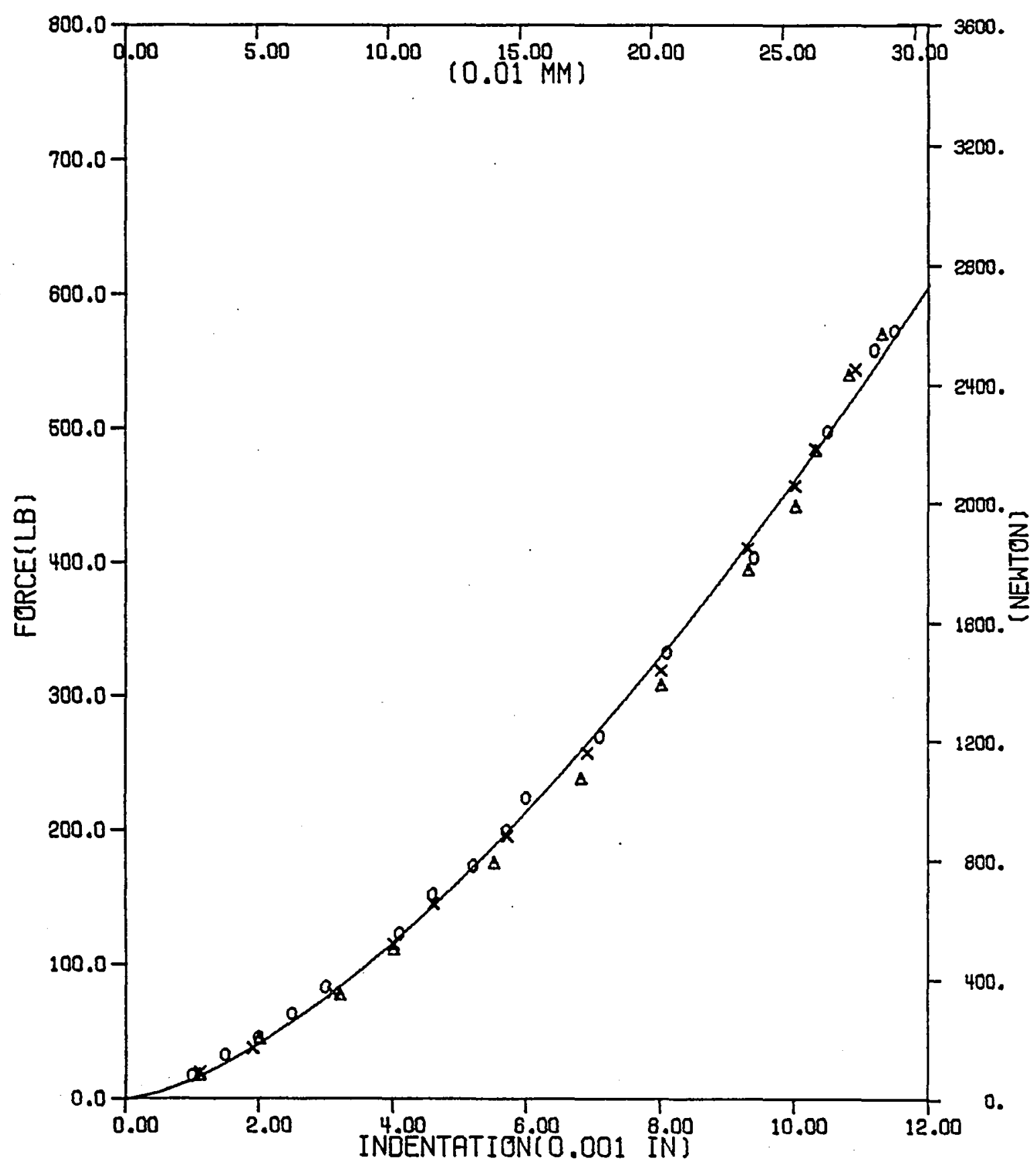

Fig. 3 - Least-square fit for loading with $n=1.5$ for glass/epoxy with $50.8 \mathrm{~mm}\left(2^{\prime \prime}\right)$-span and $6.35 \mathrm{~mm}\left(0.25^{\prime \prime}\right)$ diameter indentor. 


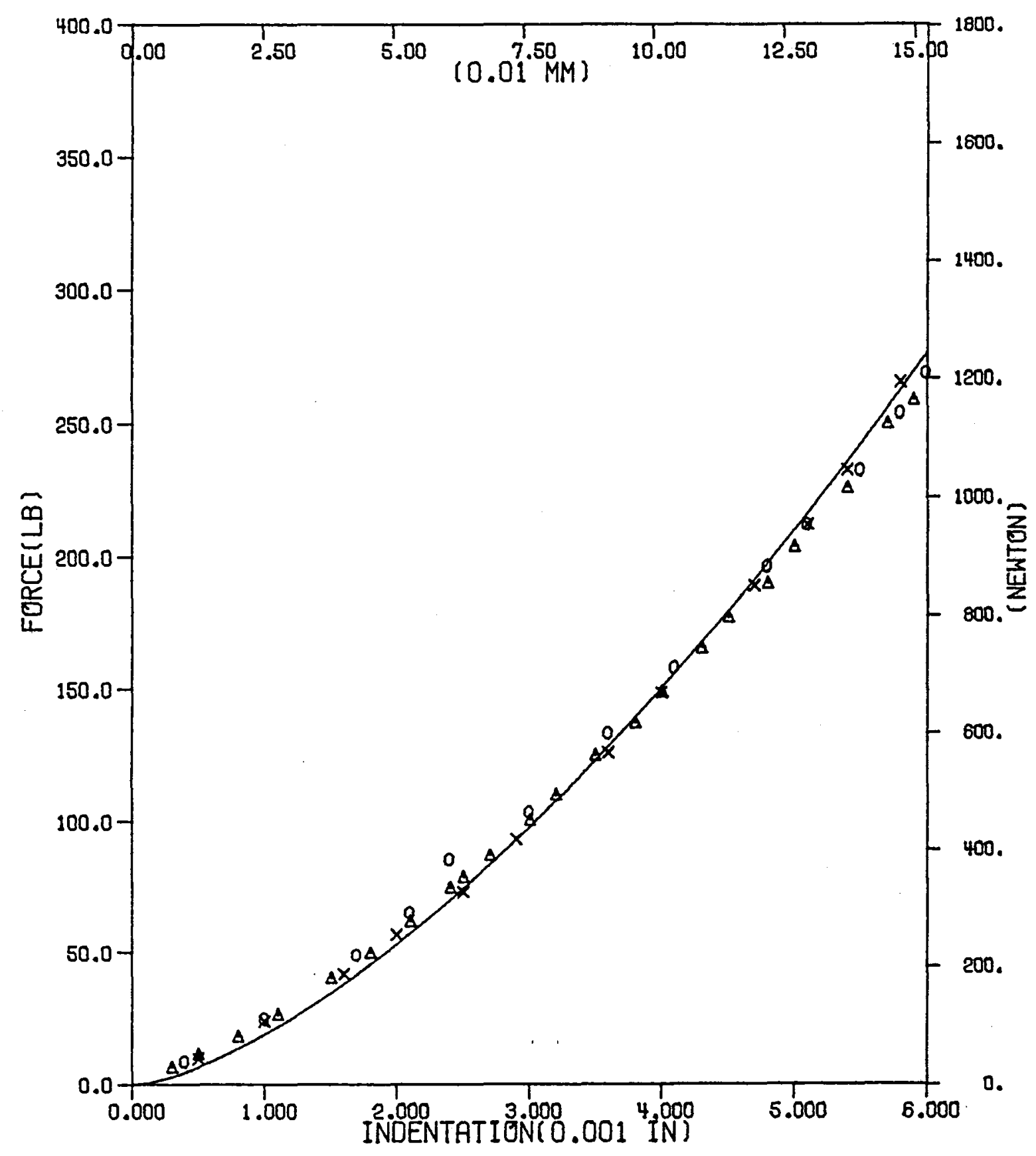

Fig. 4 - Least-square fit for loading with $n=1.5$ for graphite/epoxy with $50.8 \mathrm{~mm}\left(2^{\prime \prime}\right)$-span $25.4 \mathrm{~mm}$-width, and $6.35 \mathrm{~mm}\left(0.25^{\prime \prime}\right)$ indentor. 


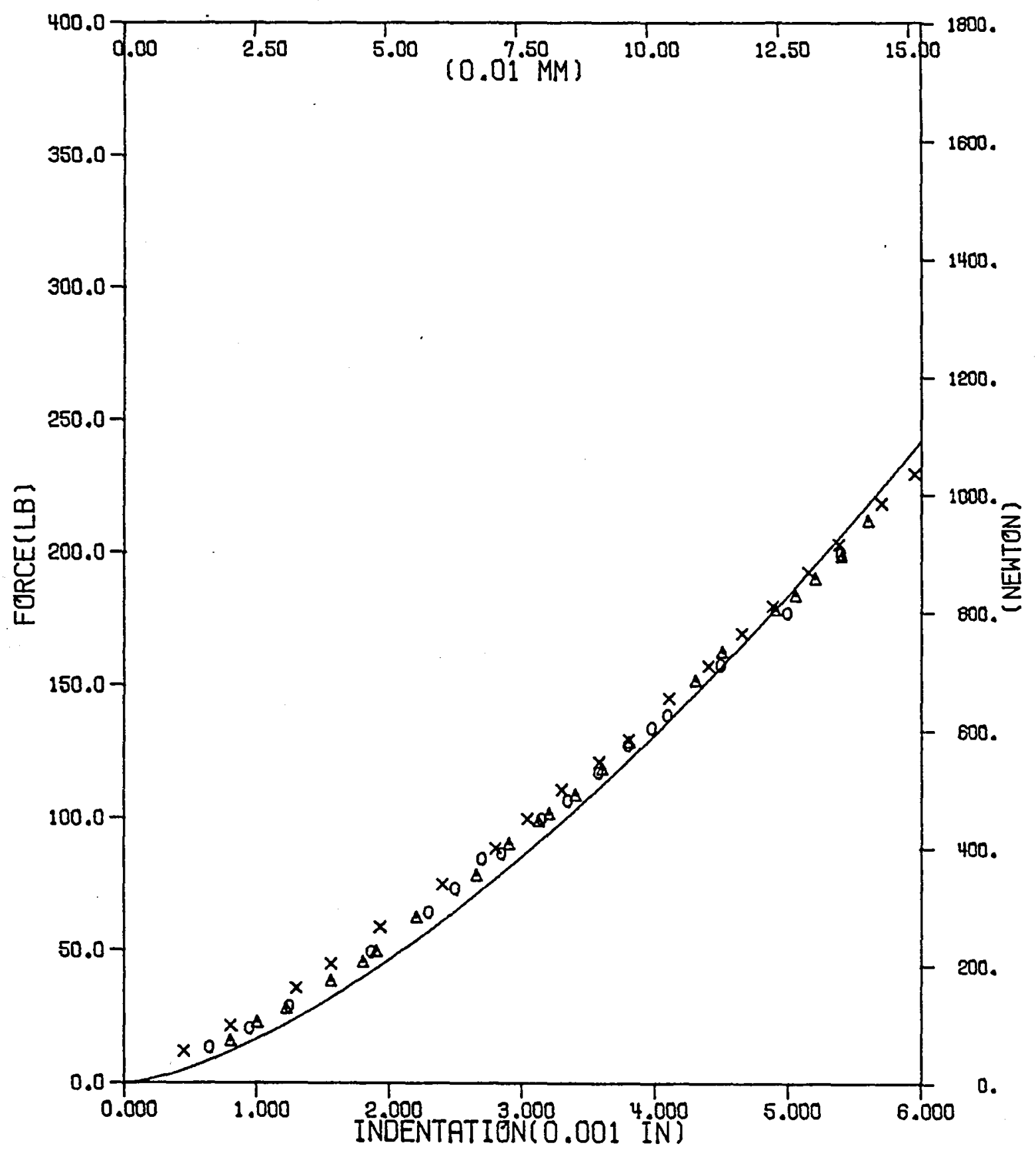

Fig. 5 - Least-square fit for loading with $n=1.5$ for graphite/epoxy with $101.6 \mathrm{~mm}\left(4^{\prime \prime}\right)-\mathrm{span}, 25.4 \mathrm{~mm}$-width, and $6.35 \mathrm{~mm}\left(0.25^{\prime \prime}\right)$ indentor. 


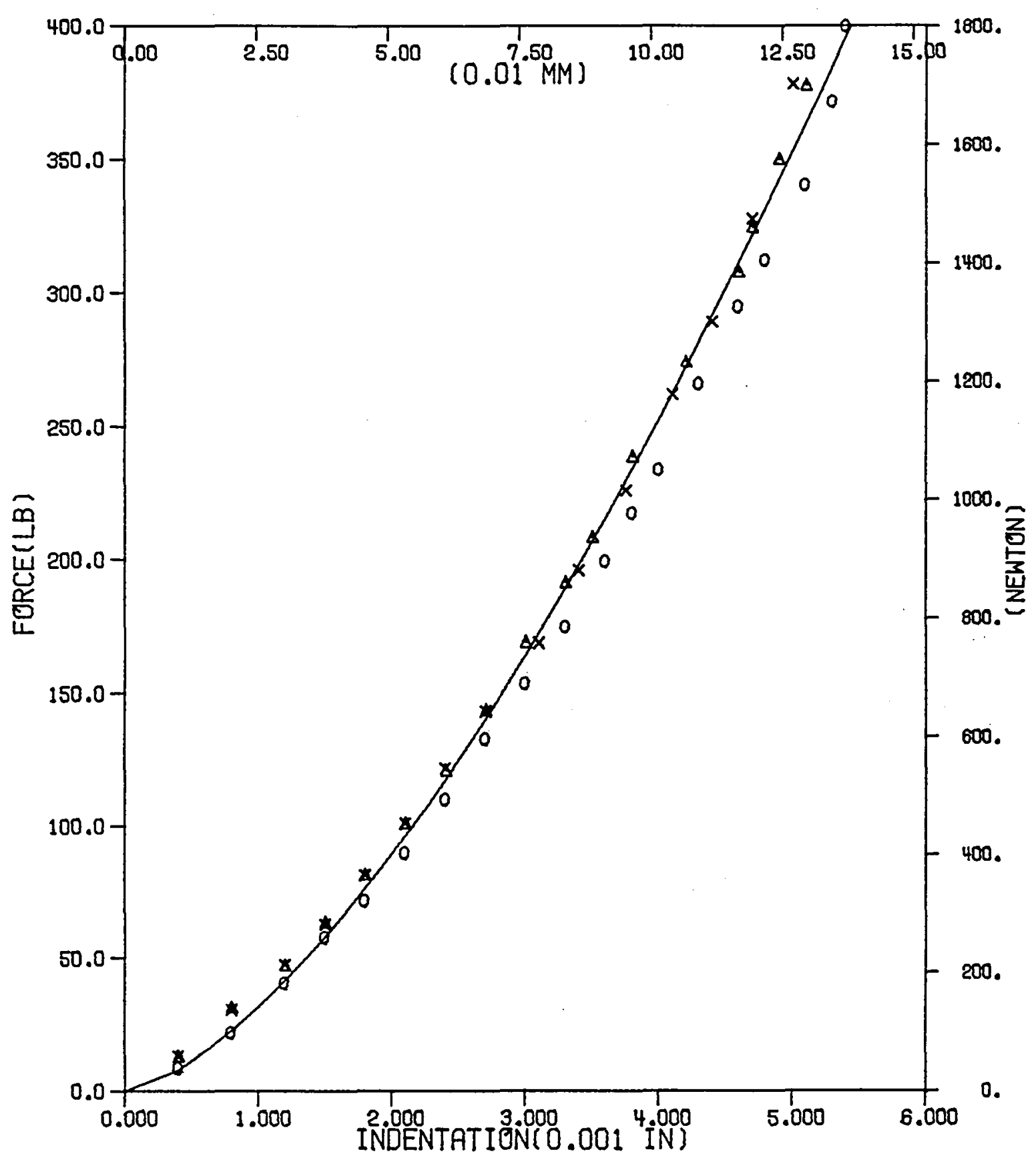

Fig. 6 - Least-square fit for loading with $n=1.5$ for graphite/epoxy with $50.8 \mathrm{~mm}\left(2^{\prime \prime}\right)-\operatorname{span}, 25.4 \mathrm{~mm}\left(1^{\prime \prime}\right)$-width, and $12.7 \mathrm{~mm}\left(0.5^{\prime \prime}\right)$ indentor. 


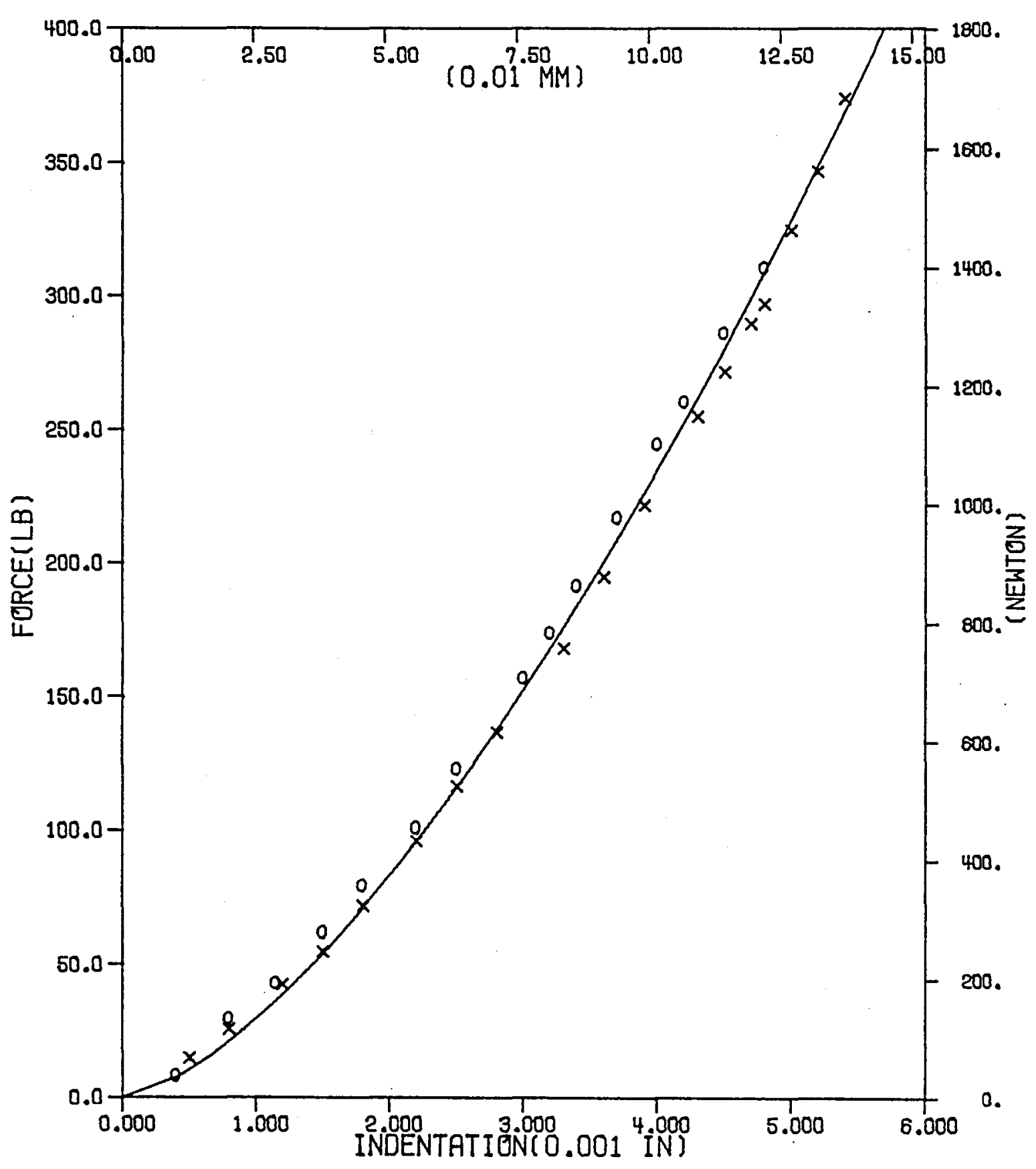

Fig. 7 - Least-square fit for loading with $n=1.5$ for graphite/epoxy with $101.6 \mathrm{~mm}\left(4^{\prime \prime}\right)$-span, $25.4 \mathrm{~mm}\left(1^{\prime \prime}\right)$-width, and $12.7 \mathrm{~mm}\left(0.5^{\prime \prime}\right)$ indentor. 


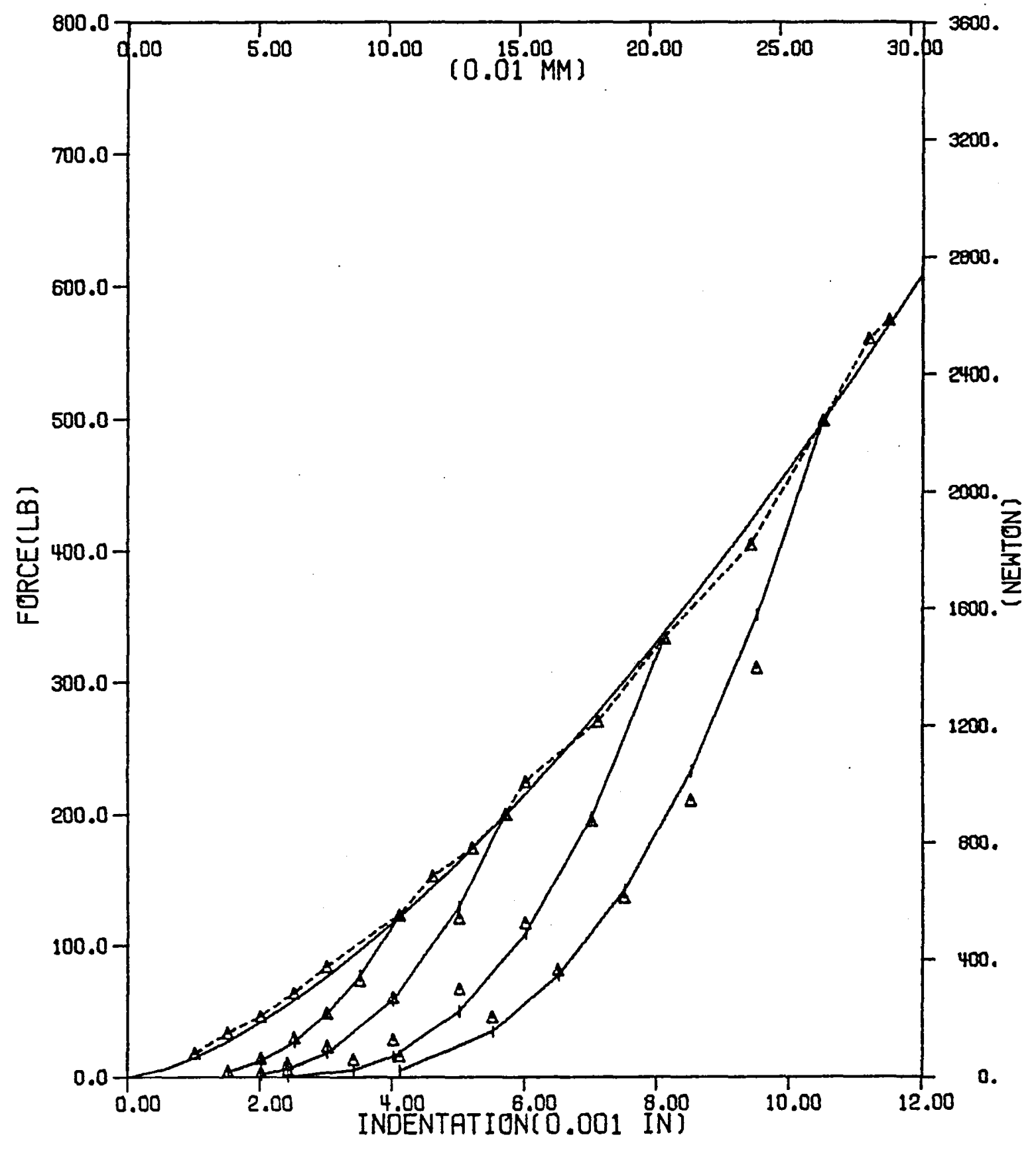

Fig. 8 - Unloading curves for glass/epoxy with $q=2.5,50.8 \mathrm{~mm}\left(2^{\prime \prime}\right)$ span and $6.35 \mathrm{~mm}\left(0.25^{\prime \prime}\right)$ indentor. 


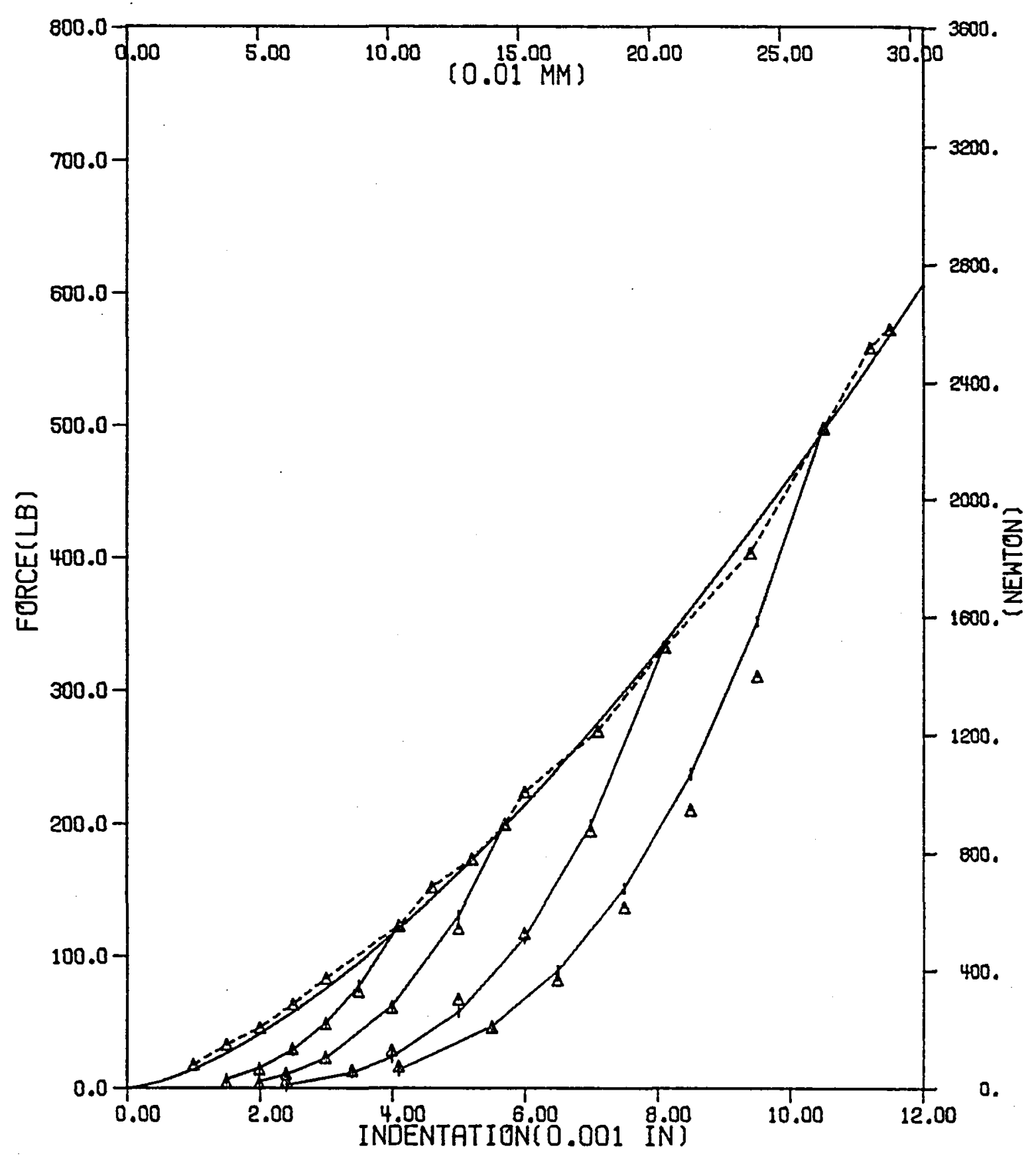

Fig. 9 - Unloading curves for glass/epoxy with $q=3.0,50.8 \mathrm{~mm}\left(2^{\prime \prime}\right)-$ span, and $6.35 \mathrm{~mm}\left(0.25^{\prime \prime}\right)$ indentor. 


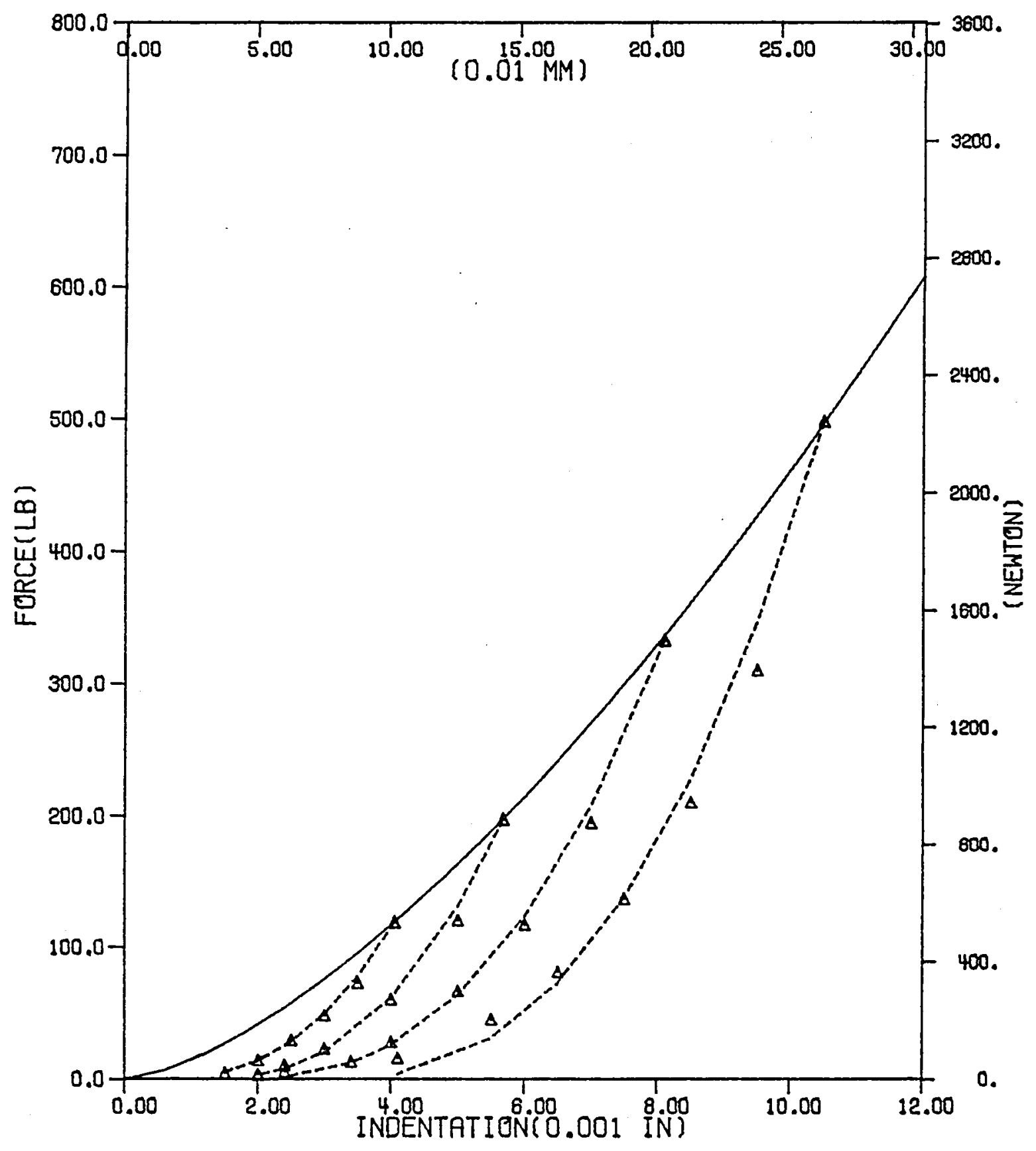

Fig. 10 - Unloading curves for glass/epoxy with $50.8 \mathrm{~mm}\left(2^{\prime \prime}\right)$-span and $6.35 \mathrm{~mm}(0.25)$ indentor using area fit. 


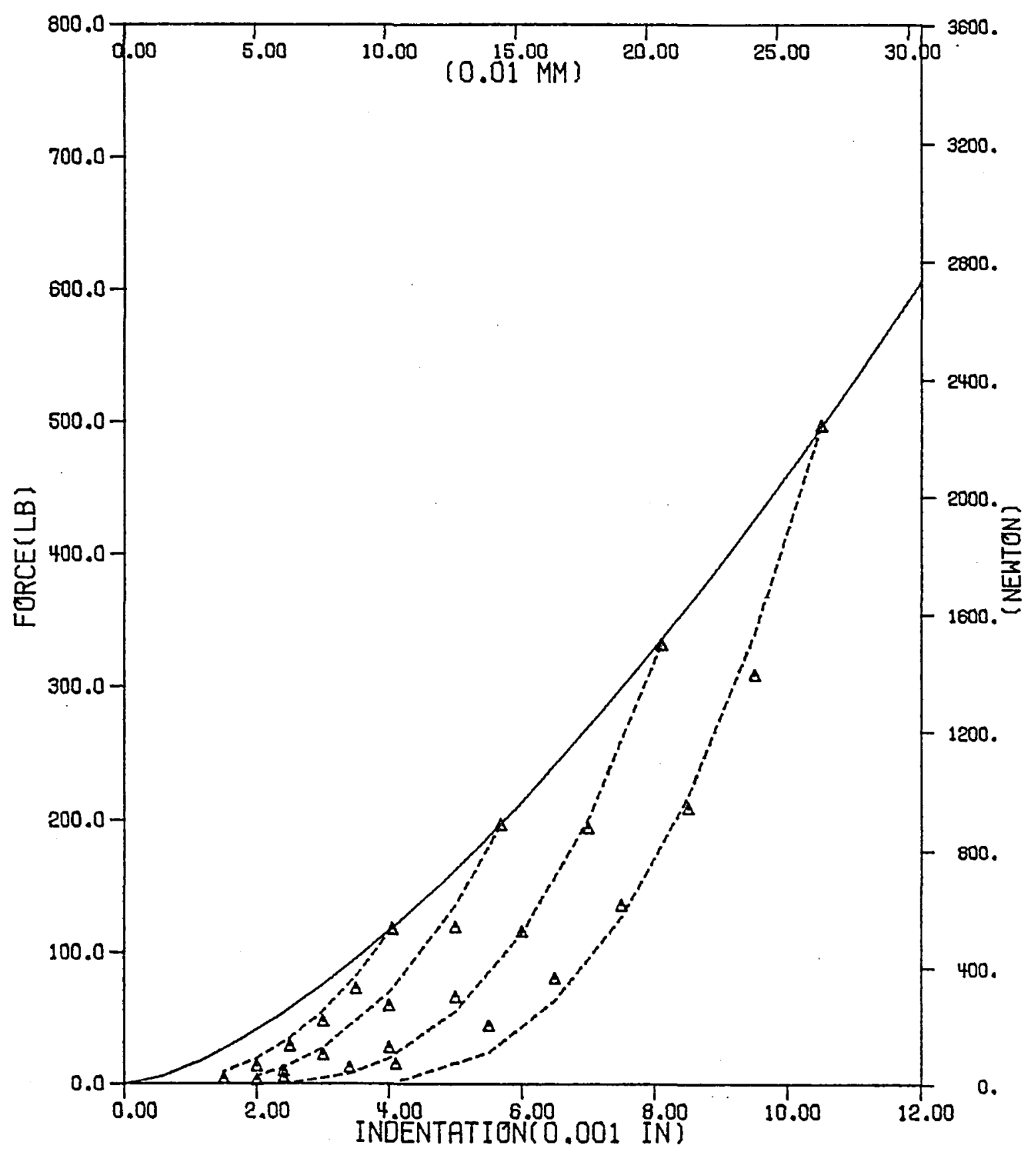

Fig. 11 - Unloading curves for glass/epoxy with $50.8 \mathrm{~mm}\left(2^{\prime \prime}\right)$-span and $6.35 \mathrm{~mm}\left(0.25^{\prime \prime}\right)$ indentor using $\alpha_{\mathrm{cr}}=0.102 \mathrm{~mm}\left(0.004^{\prime \prime}\right)$. 


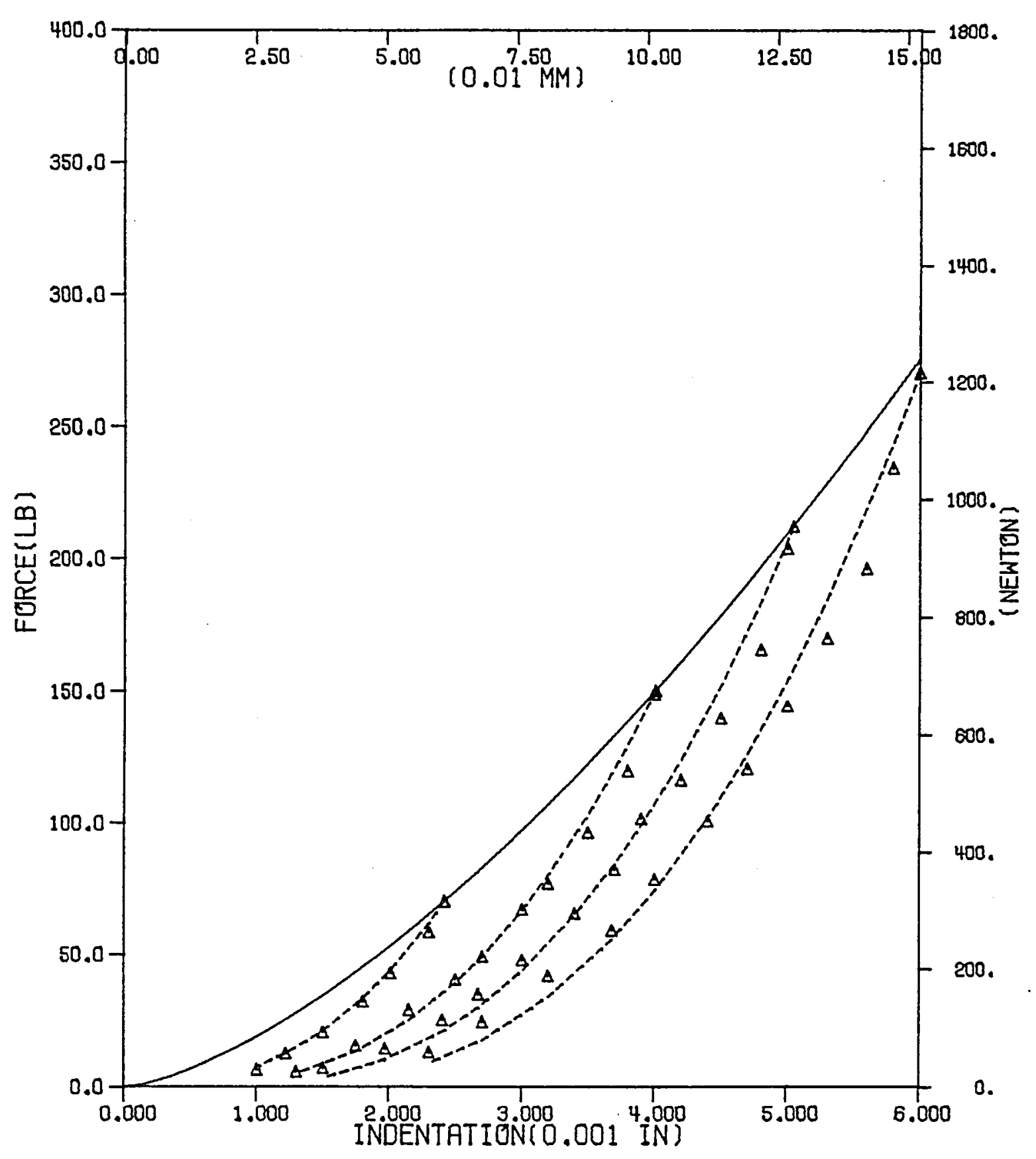

Fig. 12 - Unloading curves for graphite/epoxy with $50.8 \mathrm{~mm}\left(2^{\prime \prime}\right)$-span, $25.4 \mathrm{~mm}\left(7^{\prime \prime}\right)$-width and $6.35 \mathrm{~mm}\left(0.25^{\prime \prime}\right)$ indentor using area fit. 


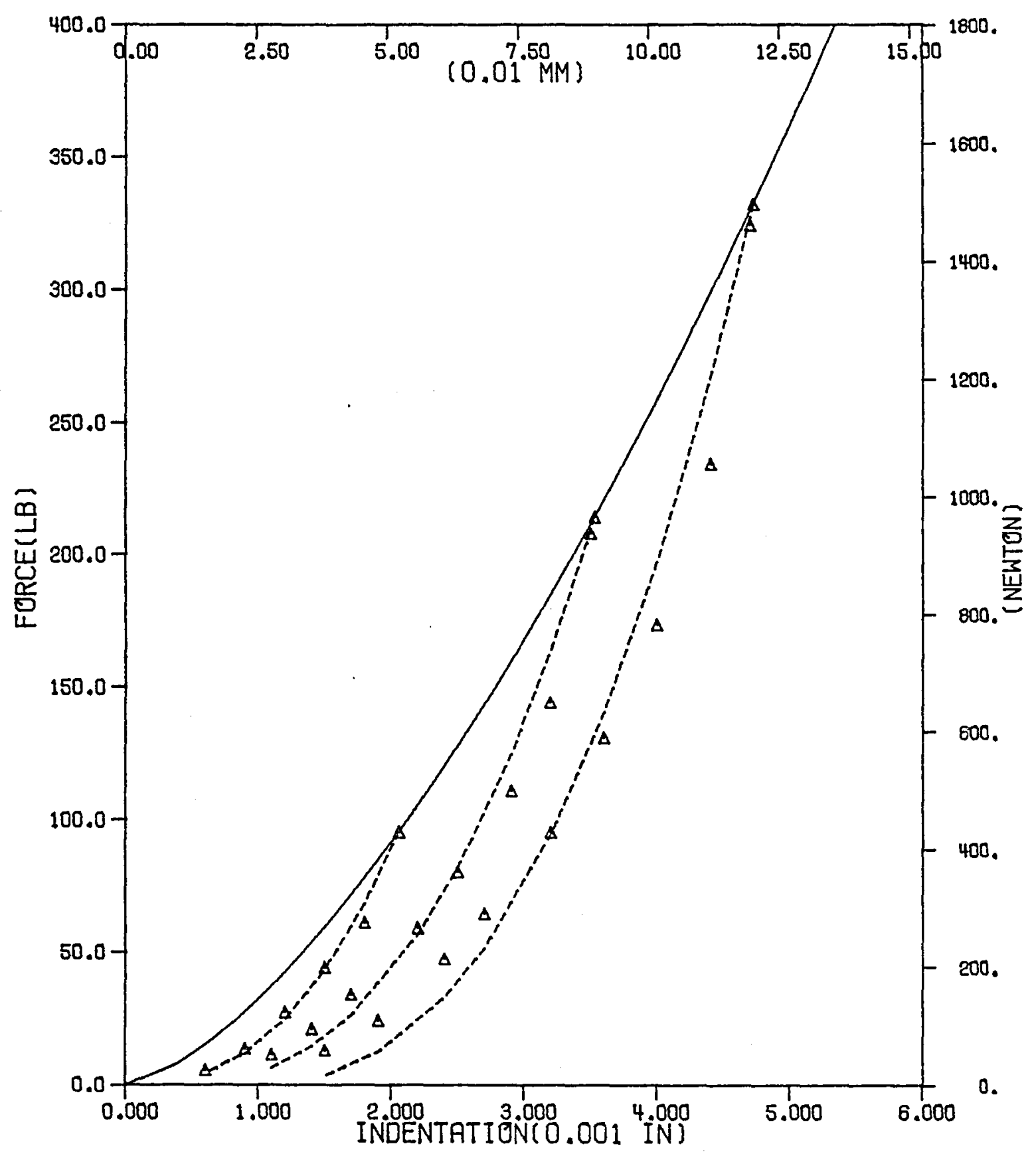

Fig. 13 - Unloading curves for graphite/epoxy with $50.8 \mathrm{~mm}\left(2^{\prime \prime}\right)$-span, $25.4 \mathrm{~mm}\left(l^{\prime \prime}\right)$-width, and $12.7 \mathrm{~mm}\left(0.5^{\prime \prime}\right)$ indentor using area fit. 


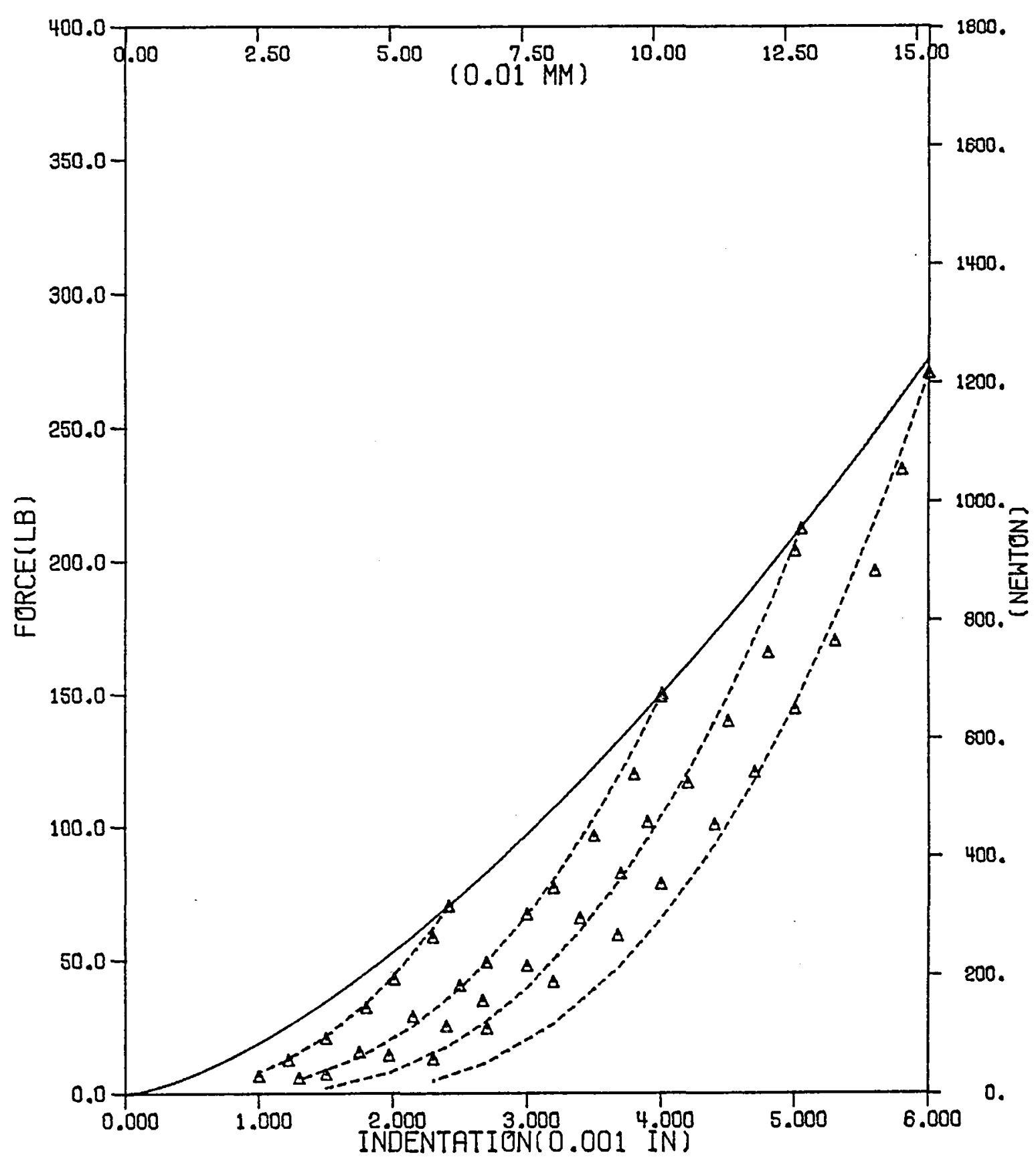

Fig. 14 - Unloading curves for graphite/epoxy with $50.8 \mathrm{~mm}\left(2^{\prime \prime}\right)$-span, 25. mm( (1")-width, and $6.35 \mathrm{~mm}\left(0.25^{\prime \prime}\right)$ indentor using $\alpha_{\mathrm{cr}}=$ $0.0803 \mathrm{~mm}\left(0.00316^{\prime \prime}\right)$. 


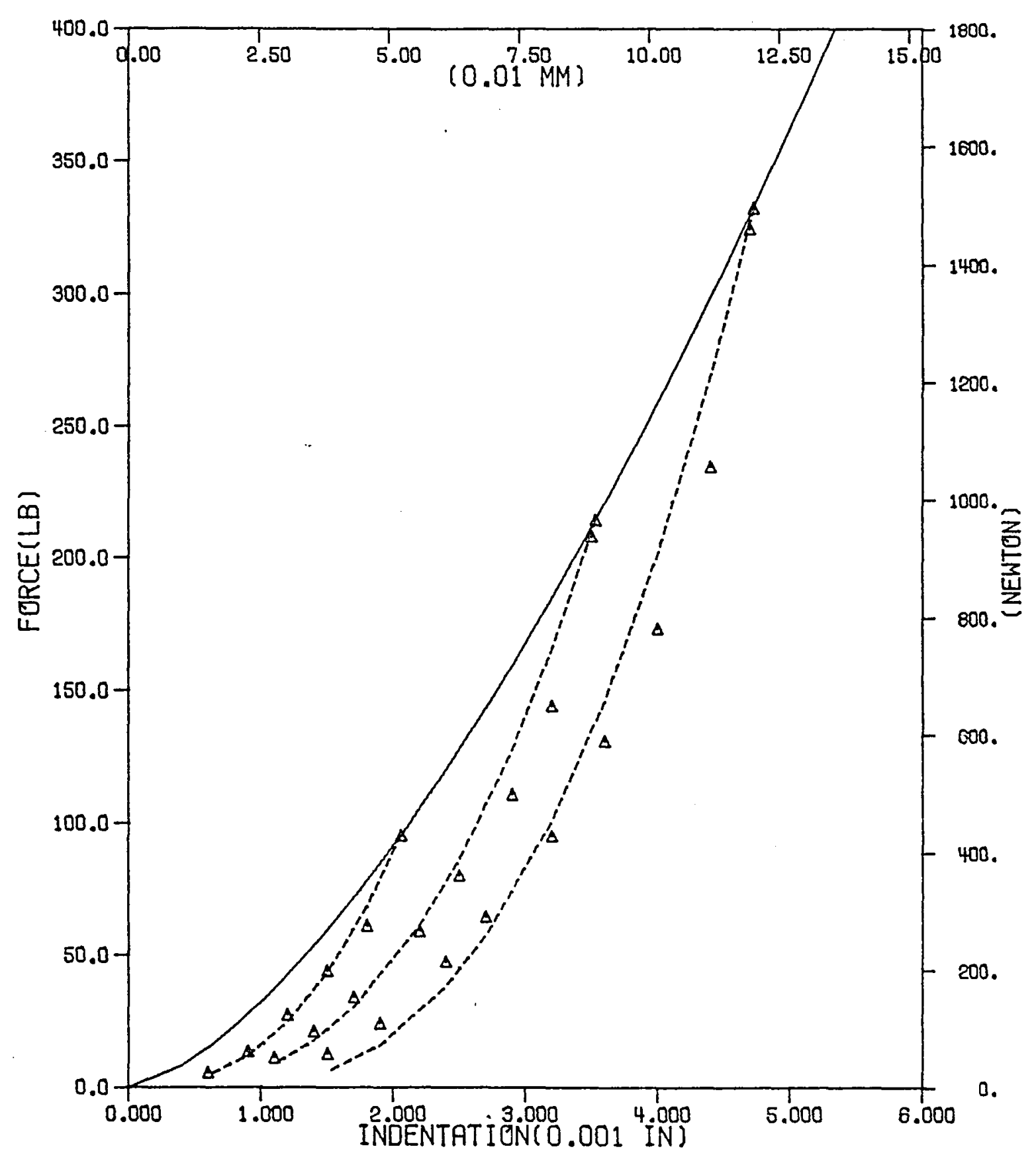

Fig. 15 - Unloading curves for graphite/epoxy with $50.8 \mathrm{~mm}\left(2^{\prime \prime}\right)$-span, $25.4 \mathrm{~mm}\left(1^{\prime \prime}\right)$-width, and $12.7 \mathrm{~mm}\left(0.5^{\prime \prime}\right)$ indentor using $\alpha_{\mathrm{cr}}=$
$0.0803 \mathrm{~mm}\left(0.00316^{\prime \prime}\right)$. 


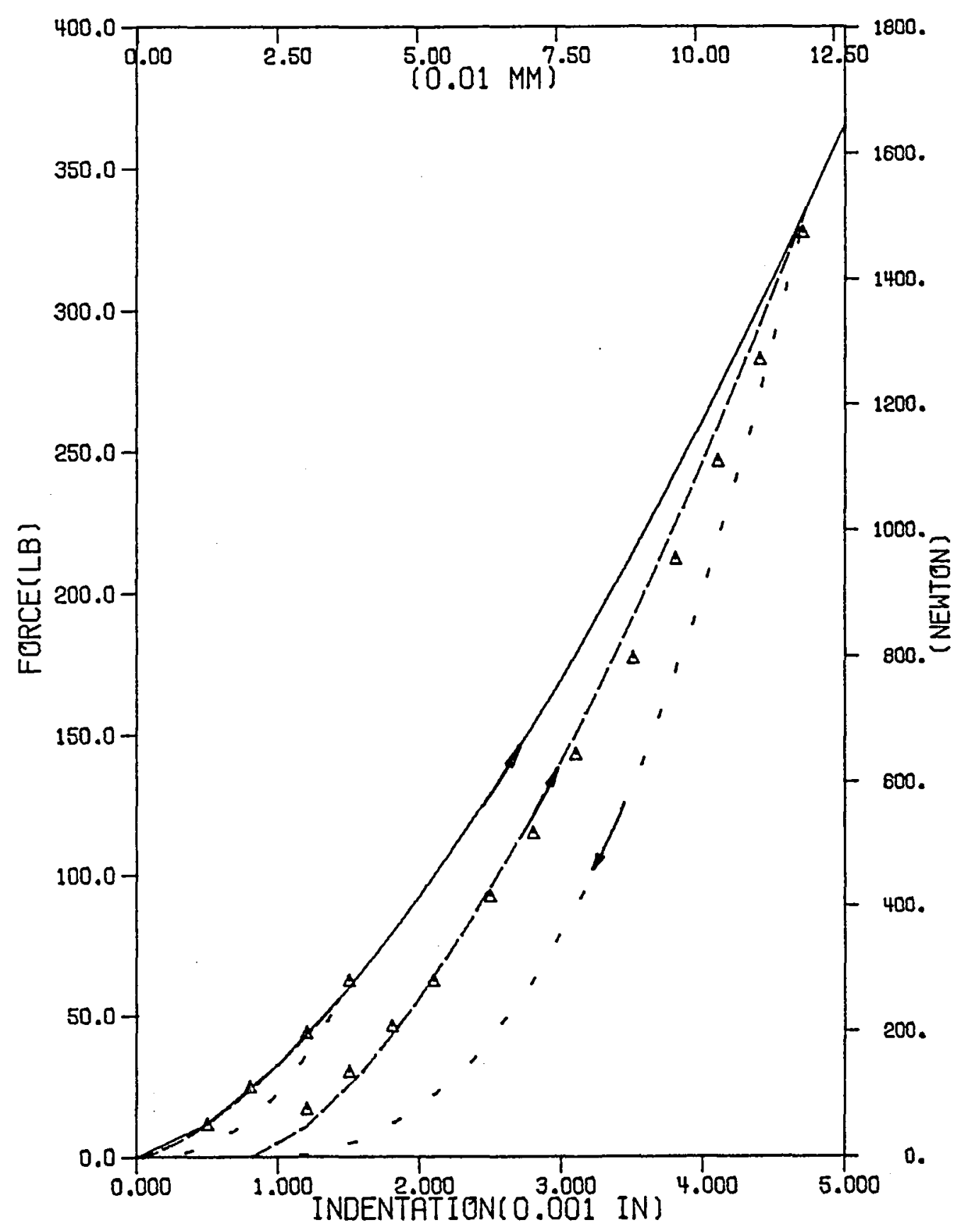

Fig. 16 - Reloading curves for graphite/epoxy with $50.8 \mathrm{~mm}\left(2^{\prime \prime}\right)$-span and $12.7 \mathrm{~mm}\left(0.5^{\prime \prime}\right)$ indentor. 


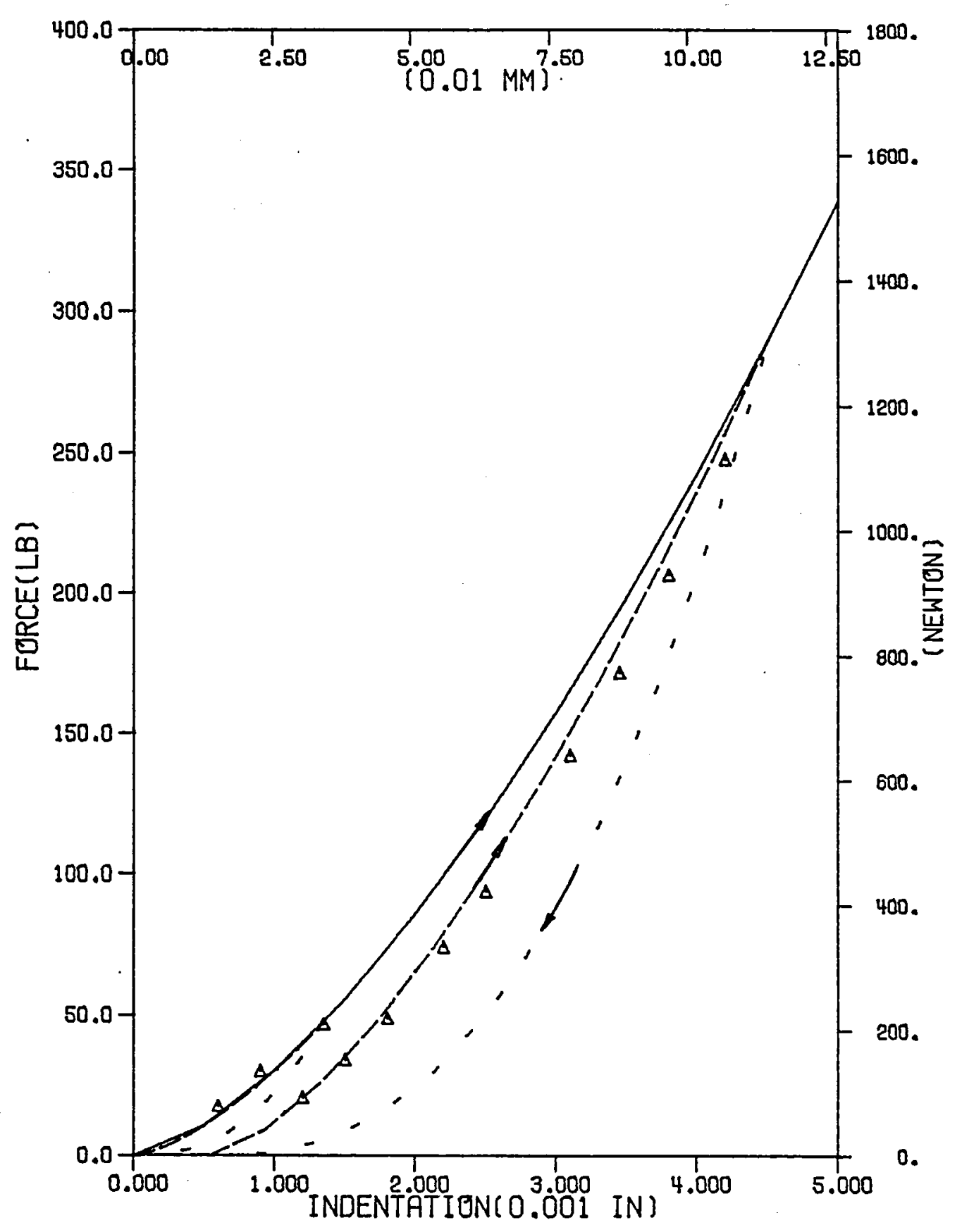

Fig. 17 - Reloading curves for graphite/epoxy with $101.6 \mathrm{~mm}\left(4^{\prime \prime}\right)$-span and $12.7 \mathrm{~mm}\left(0.5^{\prime \prime}\right)$ indentor. 
NSG-3185

INDENTATION LAW FOR COMPOSITE LAMINATES

NASA CR-165460

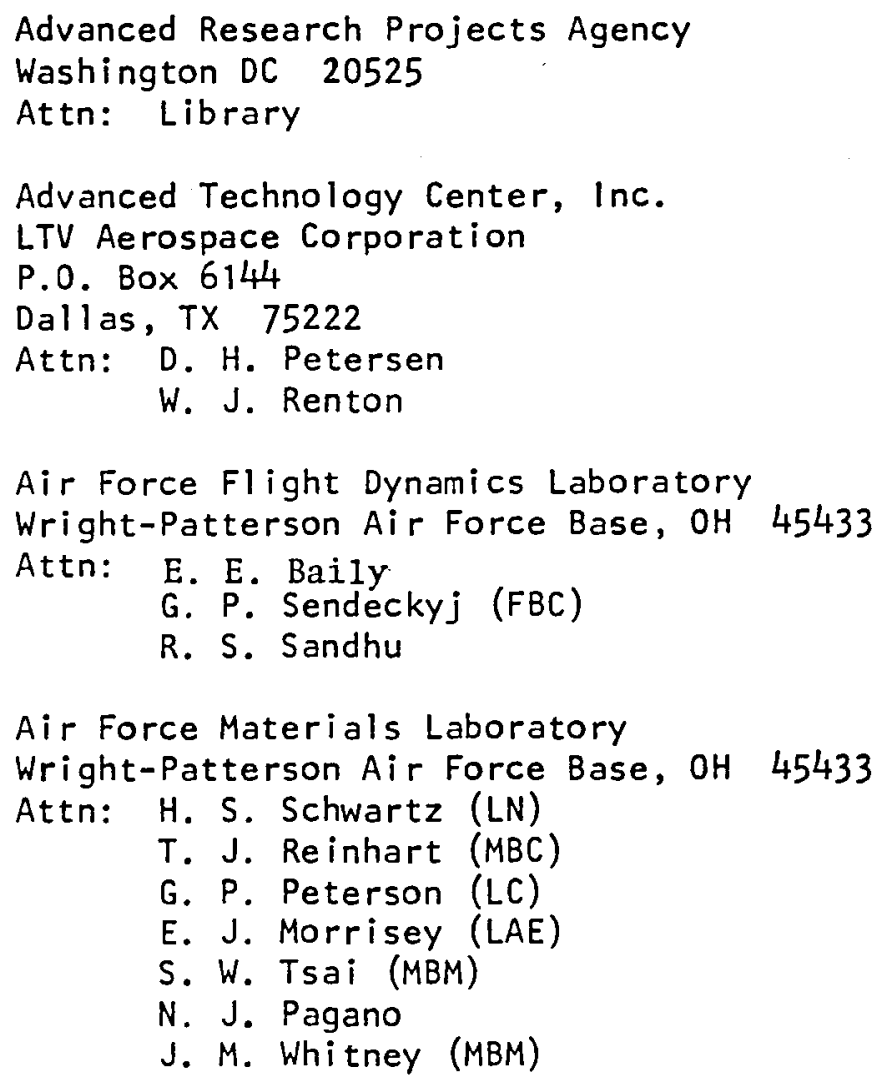

Air Force Office of Scientific Research Washington DC 20333

Attn: J. F. Masi (SREP)

Air Force Office of Scientific Research $1400 \mathrm{Wilson}$ Blvd. Arlington, VA 22209

AFOSR/NA

Bolling AFB, DC 20332

Attn:

A. K. Amos

Air Force Rocket Propulsion Laboratory

Edwards, CA 93523

Attn: Library 
Babcock \& Wilcox Company

Advanced Composites Department

P.0. Box 419

Alliance, Ohio 44601

Attn: P. M. Leopold

Bell Helicopter Company

P.0. Box 482

Ft. Worth, TX 76101

Attn: H. Zinberg

The Boeing Company

P. 0. Box 3999

Seattle, WA 98124

Attn: J. T. Hoggatt, MS. 88-33

T. R. Porter

The Boeing Company

Vertol Division

Morton, PA 19070

Attn: E. C. Durchlaub

Battelle Memorial Institute

Columbus Laboratories

505 King Avenue

Columbus, $\mathrm{OH} 43201$

Attn: L. E. Hulbert

Bendix Advanced Technology Center 9140 0ld Annapolis Rd/Md. 108

Columbia, MD 21045

Attn: 0. Hayden Griffin

Brunswick Corporation

Defense Products Division

P. 0. Box 4594

43000 Industrial Avenue

Lincoln, NE 68504

Attn: R. Morse

Celanese Research Company

86 Morris Ave.

Summit, NJ 07901

Attn: H. S. Kliger

Commander

Natick Laboratories

U. S. Army

Natick, MA 01762

Attn: Library 


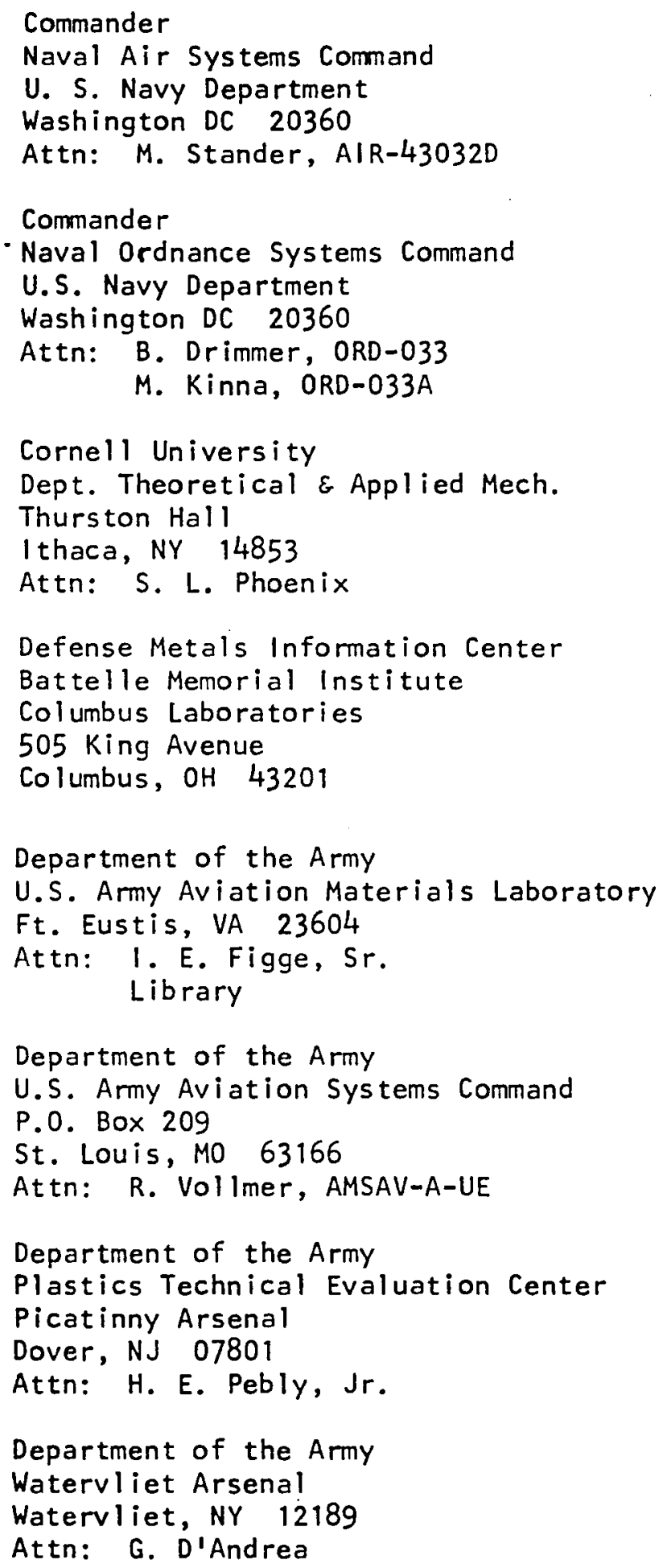




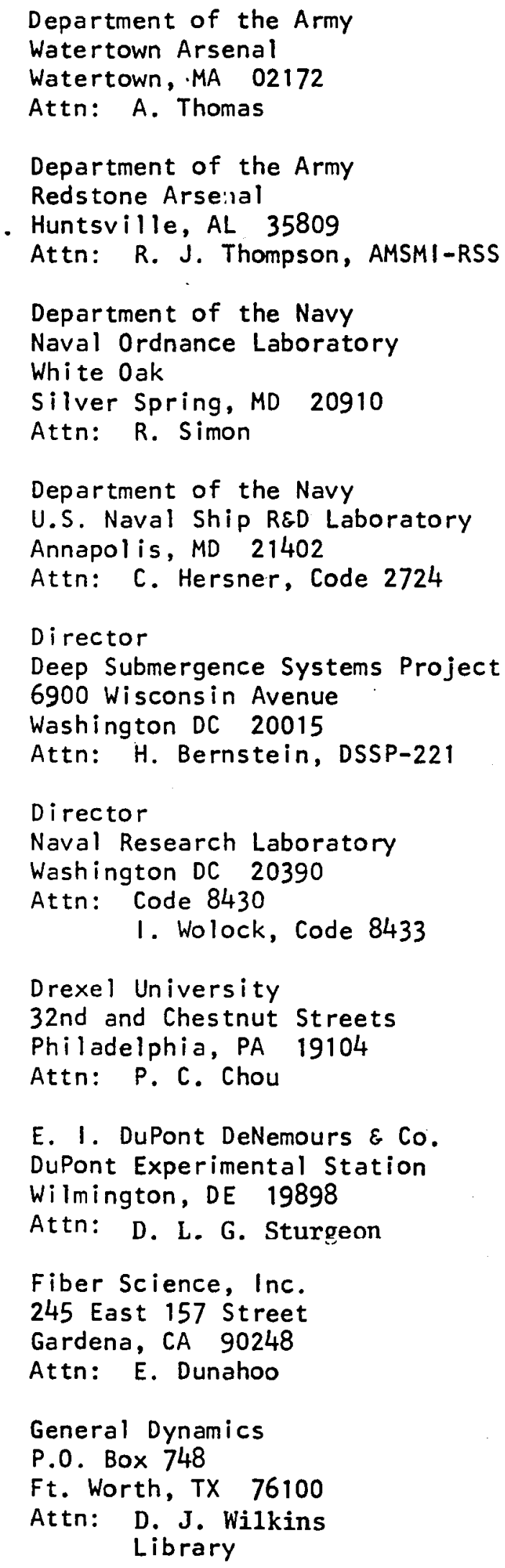


General Dynamics/Convair

P.0. Box 1128

San Diego, CA 92112

Attn: J. L. Christian

R. Adsit

General Electric Co.

Evendale, $\mathrm{OH} 45215$

Attn: C. Stotler

R. Ravenhall

General Motors Corporation

Detroit Diesel-Allison Division

Indianapolis, IN 46244

Attn: M. Herman

Georgia Institute of Technology

School of Aerospace Engineering

Atlanta, GA 30332

Attn: L. W. Rehfield

Grumman Aerospace Corporation

Bethpage, Long 1 sland, NY 11714

Attn: S. Dast in

J. B. Whiteside

Hamilton Standard Division

United Aircraft Corporation

Windsor Locks, CT 06096

Attn: W. A. Percival

Hercules, Inc.

Allegheny Ballistics Laboratory

P. 0. Box 210

Cumberland, MD 21053

Attn: A. A. Vicario

Hughes Aircraft Company

Culver City, CA 90230

Attn: A. Knoell

Illinois Institute of Technology

10 West 32 Street

Chicago, IL 60616

Attn: L. J. Broutman

IIT Research Institute

10 West 35 Street

Chicago, IL 60616

Attn: I. M. Daniel

Jet Propulsion Laboratory

4800 Oak Grove Drive

Pasadena, CA 91103

Attn: Library 
Lawrence Livermore Laboratory

P. 0. Box 808, L-421

Livermore, CA 94550

Attn: T. T. Chiao

E. M. Wu

Lehigh University

Institute of Fracture $\varepsilon$

Solid Mechanics

Bethlehem, PA 18015

Attn: G. C. Sih

Lockheed-Georgia Co.

Advanced Composites Information Center

Dept. 72-14, Zone 402

Marietta, GA 30060

Attn: T. M. Hsu

Lockheed Missiles and Space Co.

P.0. Box 504

Sunnyvale, CA 94087

Attn: R. W. Fenn

Lockheed-Cal i fornia

Burbank, CA 91503

Attn: J. T. Ryder

K. N. Lauraitis

J. C. Ekvall

McDonnell Douglas Aircraft Corporation P.0. Box 516

Lambert Field, MS 63166

Attn: J. C. Watson

McDonnell Douglas Aircraft Corporation 3855 Lakewood Blvd.

Long Beach, CA 90810

Attn: L. B. Greszczuk

Material Sciences Corporation

1777 Walton Road

Blue Bell, PA 19422

Attn: B. W. Rosen

Massachusetts Institute of Technology

Cambridge, MA 02139

Attn: F. J. McGarry

J. F. Mandel 1

J. W. Mar

NASA-Ames Research Center

Moffett Field, CA 94035

Attn: Dr. J. Parker

Library 
NASA-Flight Research Center

P.0. Box 273

Edwards, CA 93523

Attn: Library

NASA-George C. Marshall Space Flight Center

Huntsville, AL 35812

Attn: C. E. Cataldo, SEE-ASTN-MX

Library

NASA-Goddard Space Flight Center

Greenbelt, MD 20771

Attn: Library

NASA-Langley Research Center

Hampton, VA 23365

Attn: J. H. Starnes

J. G. Davis, Jr.

M. C. Card

J. R. Davidson

NASA-Lewis Research Center

21000 Brookpark Road, Cleveland, OH 44135

Attn: Contracting officer, MS 501-11

Tech. Report Control, MS 5-5

Tech. Utilization, MS 3-16

AFSC Liaison, MS 501-3

SEMTD Contract Files, MS 49-6

L. Berke, MS 49-6

N. T. Saunders, MS 49-1

R. F. Lark, MS 49-6

J. A. Ziemianski, MS 49-6

R. H. Johns, MS 49-6

C. C. Chamis, MS 49-6 (8 copies)

R. L. Thompson, MS 49-6

T. T. Serafini, MS 49-1

Library, MS 60-3 (2 copies)

NASA-Lyndon B. Johnson Space Center

Houston, TX 77001

Attn: S. Glorioso, SMD-ES52

Library

NASA Scientific and Tech. Information Facility

P.0. Box 8757

Balt/Wash; International Airport, MD 21240

Attn: Acquisitions Branch (15 copies)

National Aeronautics \& SpaceAdministration

Office of Advanced Research \& Technology

Washington DC 20546

Attn: L. Harris, Code RTM-6

M. Greenfield, Code RTM- 6

D. J. Weidman, Code RTM-6 


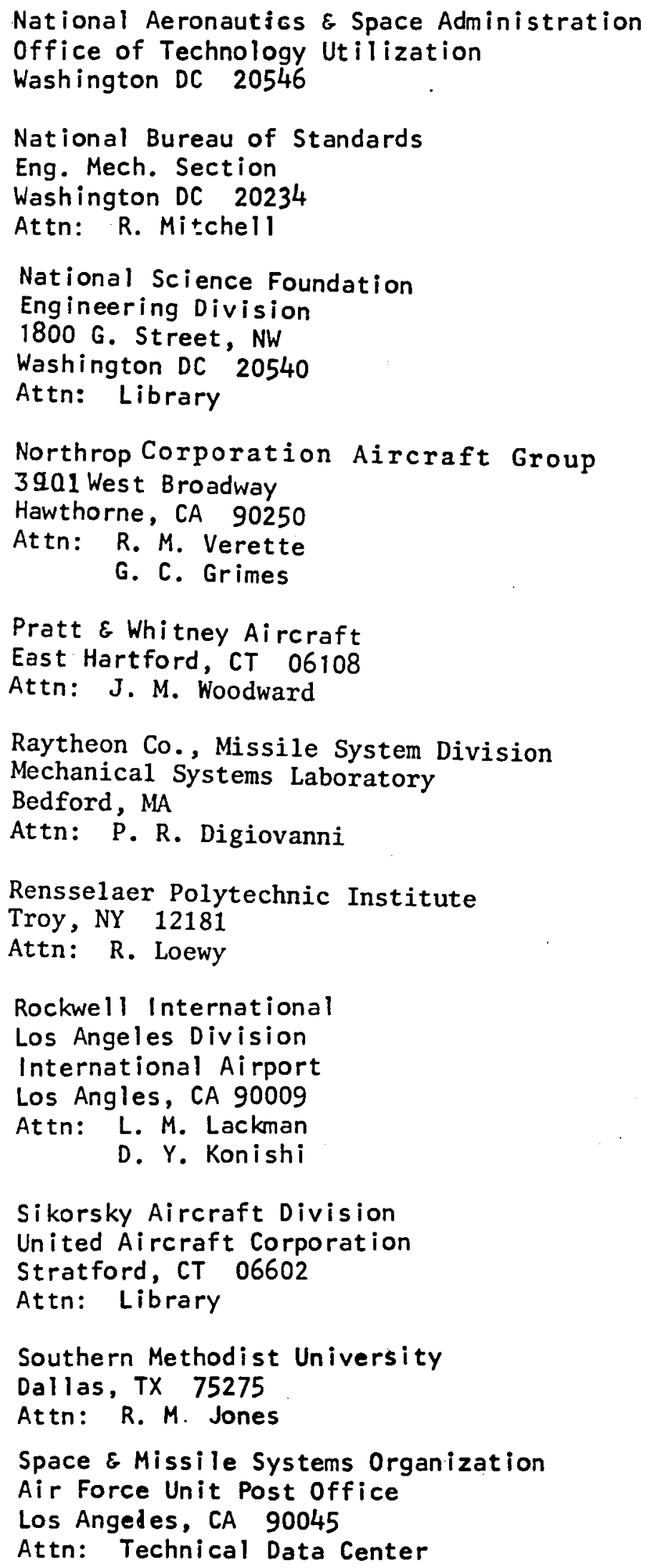

Sikorsky Aircraft Division United Aircraft Corporation Stratford, CT 06602

Attn: Library

Southern Methodist University

Dallas, TX 75275

Attn: R. M. Jones

Space \& Missile Systems Organization

Air Force Unit Post Office

Los Angedes, CA 90045

Attn: Technical Data Center 
Structural Composites Industries, Inc.

6344 N. I rwindale Avenue

Azusa, CA 91702

Attn: R. Gordon

Texas AEM

Mechanics \& Materials Research Center

College Station, TX 77843

- Attn: R. A. Schapery

Y. Weitsman

TRW, Inc.

23555 Euclid Avenue

Cleveland, $\mathrm{OH} \quad 44117$

Attn: I. J. Toth

Union Carbide Corporation

P. 0. Box 6116

$\mathrm{Cleveland,} \mathrm{OH} \quad 44101$

Attn: J. C. Bowman

United Technologies Research Center

East Hartford, CT 06108

Attn: R. C. Novak

Dr. A. Dennis

University of Dayton Research Institute

Dayton, OH 45409

Attn: R. W. Kim

University of Delaware

Mechanical \& Aerospace Engineering

Newark, DE 19711

Attn: B. R. Pipes

University of Illinois

Department of Theoretical \& Applied Mechanics

Urbana, IL 61801

Attn: S. S. Wang

University of $0 \mathrm{klahoma}$

School of Aerospace Mechanical \& Nuclear Engineering

Norman, OK 73069

Attn: C. W. Bert

University of Wyoming

College of Engineering

University Station Box 3295

Laramie, WY 82071

Attn: D. F. Adams

U. S. Army Materials \& Mechanics Research Center

Watertown Arsenal

Watertown, MA 02172

Attn: E. M. Lenoe

D. W. Oplinger 
V.P. I. and S. U.

Dept. of Eng. Mech.

Blacksburg, VA 24061

Attn: R. H. Heller

H. J. Brinson

C. T. Herakovich

K. L. Reifsnider 


\section{End of Document}

